\title{
Prospects for Titanium-Based Materials as Truck Disc Brake Rotors
}

\author{
May 14, 2007 \\ Peter J. Blau \\ Materials Science and Technology Division \\ Oak Ridge National Laboratory
}


This research was sponsored by the U.S. Department of Energy, Assistant Secretary for Energy Efficiency and Renewable Energy, Office of FreedomCAR and Heavy Vehicle Technologies, as part of the Automotive Lightweighting Materials Program, under contract DE-AC05-00OR22725 with UTBattelle, LLC 


\section{DOCUMENT AVAILABILITY}

Reports produced after January 1, 1996, are generally available free via the U.S. Department of Energy (DOE) Information Bridge:

Web site: http://www.osti.gov/bridge

Reports produced before January 1, 1996, may be purchased by members of the public from the following source:

National Technical Information Service

5285 Port Royal Road

Springfield, VA 22161

Telephone: 703-605-6000 (1-800-553-6847)

TDD: 703-487-4639

Fax: 703-605-6900

E-mail: info@ntis.fedworld.gov

Web site: http://www.ntis.gov/support/ordernowabout.htm

Reports are available to DOE employees, DOE contractors, Energy Technology Data Exchange (ETDE) representatives, and International Nuclear Information System (INIS) representatives from the following source:

Office of Scientific and Technical Information

P.O. Box 62

Oak Ridge, TN 37831

Telephone: 865-576-8401

Fax: 865-576-5728

E-mail: reports@osti.gov

Web site: http://www.osti.gov/contact.htm

This report was prepared as an account of work sponsored by an agency of the United States Government. Neither the United States government nor any agency thereof, nor any of their employees, makes any warranty, express or implied, or assumes any legal liability or responsibility for the accuracy, completeness, or usefulness of any information, apparatus, product, or process disclosed, or represents that its use would not infringe privately owned rights. Reference herein to any specific commercial product, process, or service by trade name, trademark, manufacturer, or otherwise, does not necessarily constitute or imply its endorsement, recommendation, or favoring by the United States Government or any agency thereof. The views and opinions of authors expressed herein do not necessarily state or reflect those of the United States Government or any agency thereof. 
ORNL-TM-2007/111

PROSPECTS FOR TITANIUM-BASED MATERIALS AS TRUCK DISC BRAKE ROTORS

Peter J. Blau

Materials Science and Technology Division

Oak Ridge National Laboratory

May 14, 2007

Prepared by

OAK RIDGE NATIONAL LABORATORY

P.O. Box 2008

Oak Ridge, Tennessee 37831-6285

managed by

UT-Battelle, LLC

for the

U.S. DEPARTMENT OF ENERGY

under contract DE-AC05-00OR22725 


\section{CONTENTS}

Page

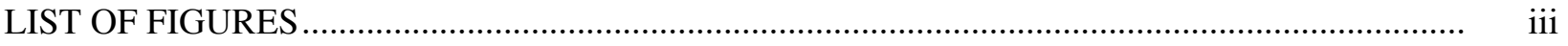

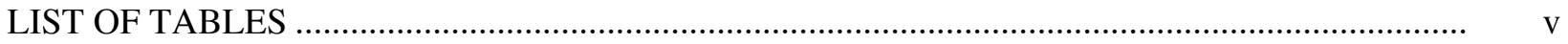

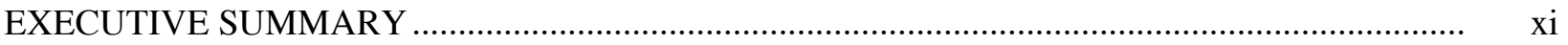

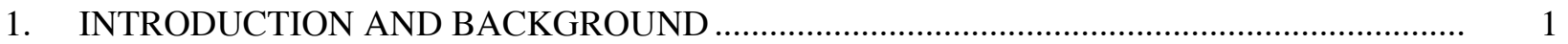

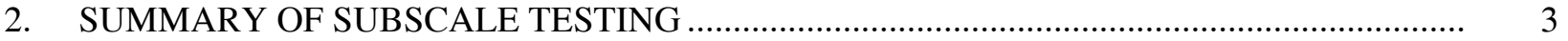

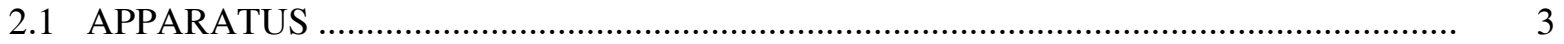

2.2 MATERIALS FOR SUB-SCALE FRICTION AND WEAR TESTS ….............................. 4

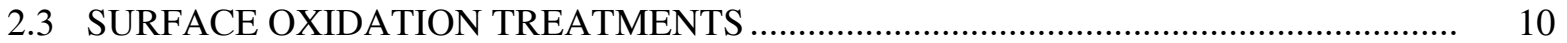

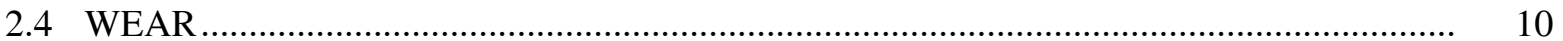

3. SUMMARY OF DYNAMOMETER TESTS ON FULL-SCALE TITANIUM ROTORS .......... 11

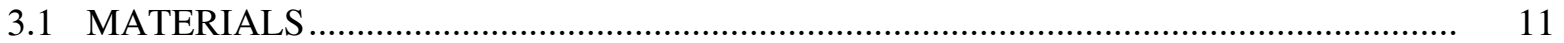

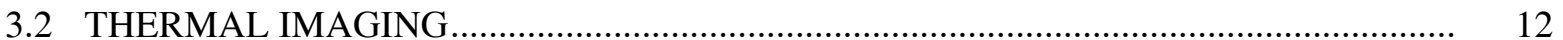

3.3 DESCRIPTION OF THE MATERIALS AND DYNAMOMETER TEST ......................... 13

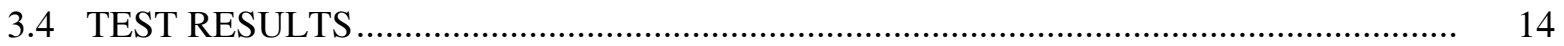

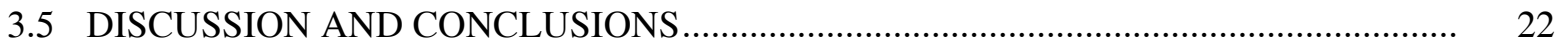

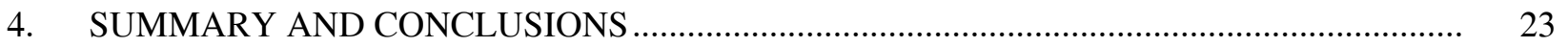

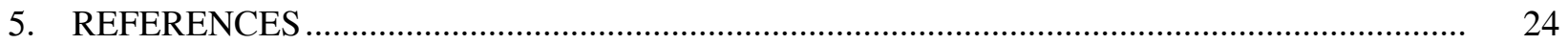




\section{LIST OF FIGURES}

Figure

Page

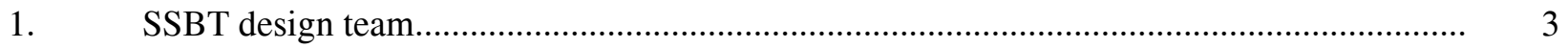

2. Schematic representation of the sub-scale brake testing system.......................................... 4

3. Average friction coefficient per drag for cast iron discs at higher normal force $(300 \mathrm{~N})$.

Each datum is the average of five drags.

4. Average friction coefficient versus sliding speed for two titanium alloys sliding against a

JURID pad

5. Average sliding friction coefficients for titanium composites against JURID pad material at different sliding speeds

6. Effect of disc surface temperature on the friction coeffieient the TSTi against Red Devil pad RD14.

7. The as-sprayed TSti showed higher friction and frictional heating than a similar deposit that was sprayed and then ground smooth.

8. Friction coefficient changes with repeated drags at various speeds for Ti+30\%TiB2 against JURID pad material.

9. OD (oxidation treated) Ti-6A1-4V alloy discs had the highest stable friction coefficient against the JURID 539 material under most test conditions.

10. Titanium alloy truck brake rotor with a protective thermally-sprayed coating applied to the friction surfaces.

11. Cross-section of the thermally-sprayed coating similar to those used in this work

12. Infrared image of a Ti-based brake rotor (similar to that in Fig. 10) undergoing repeated stops from 50 to $15 \mathrm{mph}$

13. Maximum temperatures of the rotor and pad after the last top in the hot performance series of applies

14. Minimum, maximum and average friction coefficients for all tests except the fade and hot sections of the procedure

15. Friction values for post-burnish, high-speed, and hot performance tests

16. Final pad wear loss as measured by thickness change. 


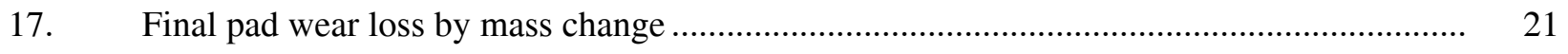

18. Final rotor wear by thickness change …................................................................ 21

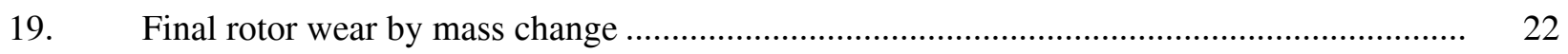




\section{LIST OF TABLES}

Table

Page

1. Titianium-Based materials Used in SSBT Tests ........................................................ 5

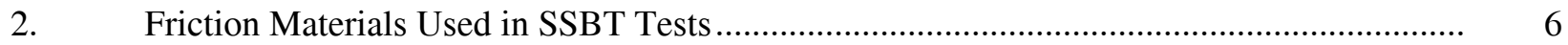

3. Combinations of Materials Subjected to Dynamometer Testing …................................... 14

4. Summary of ISO 26867 Dynamometer Test Procedure for Disc Brakes............................ 15

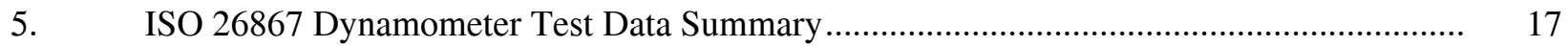

6. Summar of Temperature Data from ISO 26867 Dynamometer Tests .................................. 18 


\subsection{INTRODUCTION AND BACKGROUND}

Strategies to improve the energy efficiency of cars and trucks can take many forms, like reducing parasitic frictional losses in the engine and drive-train, reducing rolling resistance of the tires, and designing the shape of vehicles for lower aerodynamic drag. With these strategies to reduce drag comes the penalty of making the vehicles harder to stop. Therefore, several research projects were begun under Department of Energy sponsorship to evaluate lightweight materials for new energy-efficient brakes. There was no pre-conceived notion as to what kinds of materials these would be, and research included ceramic composites, graphite materials, aluminum-based composites, and titanium-based composites. Cast iron was used as a benchmark in these studies since most current ground vehicle brake materials are cast iron or steel.

Structural materials used in brakes have to fulfill a combination of functions. They must be dependable, durable, corrosion resistant, structurally-sound, and economically viable. Two general types of brake designs are currently used on heavy trucks: (a) drum brakes in which curved contact surfaces ('shoes') are forced outward against the inner diameter of a circular drum, and (b) disc brakes in which flat pads are clamped against a circular rotor that is attached to the wheel hub. Disc brakes are commonplace on automobiles and on some types of buses and trucks. The rotor/pad design of disc brakes tends to exhibit better resistance to fade (the decrease in friction when the brake temperature rises too high) than do drum/shoe type brakes. The European trucking industry has widely adopted disc brakes, and the U.S. trucking industry is likely to witness an increasing use of disc brakes in the face of new government-mandated, 20-30\% reductions in stopping distances. Caliper clamping forces in commercial air disc brake systems for trucks can exceed $300 \mathrm{kN}$ and the brake assembly might be called on to dissipate as much as $900 \mathrm{~kW}$ (1200 h.p.) during a single stop [1].

Most disc brake rotors in use today are made from gray cast iron, typically containing about 3.5\% carbon and various additives. Compositional modifications and heat treatments are also optimized to avoid thermal cracking and rotor distortion. In contrast to the rotors, brake pads are complex composite materials. They typically contain a phenolic resin binder with additions of mineral fibers, fillers, frictionmodifying compounds, abrasives, and metallic particles to modify heat flow characteristics. Numerous compositions of friction materials have been developed, largely by empirical testing, and as a result, they vary greatly $[2,3]$.

For over a decade the U.S. Department of Energy has supported research and development projects to improve the fuel economy of automobiles and heavy trucks. The portfolio of projects ranges from reduced aerodynamic drag to lowering engine friction and parasitic losses in the drive train. If vehicles are made to roll more easily, they also become harder to stop, and several projects were conducted to investigate alternative, light-weight materials that could improve the braking effectiveness while also contributing to energy efficiency. These materials included ceramic composites [4] and carbon-graphite materials [5] that have found limited but growing usage in high-speed trains and aircraft. However, lighter weight metallic alloys and metal matrix composites are also candidates for friction brakes. In the work reported here, the tribological characteristics of several kinds of titanium-based materials were investigated. This interest was prompted in part by recent research that promises to reduce the raw material cost of $\mathrm{Ti}$ and thus make additional applications economically feasible [6].

Except for niche racing applications [7], titanium alloys have seen little commercial use in brake rotors; however, their reduced density ( $7.4 \mathrm{~g} / \mathrm{cm} 3)$, good stiffness, relatively high-strength, and resistance to corrosive attack by ice-melting salts merited an investigation of their potential for use in future truck braking systems.

Due to the research and development effort by the aerospace and defense industries, a great deal is known about the metallurgy and processing of titanium alloys. However, their tribological characteristics are less well known. While the fretting characteristics of Ti alloys have been the subject of considerable research, relatively few papers have addressed the sliding wear and friction of titanium alloys (e.g., [8-10]). Based on published work, recent studies at Oak Ridge National Laboratory, and discussions with brake system engineers, titanium alloys are unlikely to be satisfactory rotor materials without some form of surface modification, particulate additions, or coating. While titanium-based 
alloys offer several advantages for brakes, their three major disadvantages are (1) low thermal conductivity relative to cast iron, (2) the trucking industry's lack of familiarity with the material, and (3) the cost of titanium parts. Thermal behavior is particularly relevant in terms of brake function, pad material selection, and rotor design. Cost elements include raw materials, processing, fabrication, surface treatment (if any), and machining.

The objective of this work was to investigate the friction, wear, and thermal heating characteristics of $\mathrm{Ti}$ alloys in various forms, and to compare the results to those for cast iron tested under similar conditions. The counterface materials were commercially-produced brake lining materials. A portion of these data were reported earlier [11], but the present paper includes more recently obtained data on additional Ti materials.

Non-traditional, light-weight brake rotor materials for heavy trucks have been investigated on a laboratory scale for several years under OFCVT sponsorship. An instrumented, sub-scale brake material testing system (SSBT) was built at Oak Ridge National Laboratory to support this effort and has been used extensively. The primary focus has been on the rotor material, using primarily commercial brake lining (pad) materials as the sliding counterfaces. Previously examined, rotor specimen materials have included carbon-silicon carbide composites, aluminum-based metal matrix composites, intermetallic iron aluminide alloys. Most recently, titanium alloys and composites were friction and wear-tested using the SSBT. Titanium materials are strong, stiff, and highly-resistant to road salt corrosion. While they tend to run hotter than traditional cast iron, due to their lower thermal conductivity, they seem to provide better resistance to loss of friction ("fade") at elevated temperatures.

Recent studies of thermally-sprayed titanium showed that the material offers some attractive characteristics in terms of enhanced wear resistance beyond that of non-coated titanium alloys and even titanium-based hard particle composites. Previous publications by ORNL investigators have described results using the SSBT and related laboratory-scale experiments on brake materials (e.g. [2,11-20]).

The work described here takes the development of lightweight truck brake materials a major step closer to commercial production. Full-scale thermal-sprayed titanium alloy rotors were prepared by Red Devil Brakes, Inc., of Mount Pleasant, Pennsylvania. Then, along with cast iron rotors, these were subjected to ISO standard brake test protocols at Link Testing Laboratories, Inc., of Detroit, Michigan. A summary of data from those tests are also summarized in this report. 


\section{SUMMARY OF SUBSCALE TESTING}

\subsection{APPARATUS}

A special test apparatus was designed and built in order to allow friction and wear characterization of candidate alloys and composite materials for brakes. It was designed by the author with significant assistance from R. D. Ott (ORNL), M. Mosleh (Howard University), D. Dumitrescu (U. of Michigan), and J. McLaughlin (ORNL) (Fig. 1). It uses sub-sized, flat discs to simulate the brake rotor and small blocks of friction material to slide against it.

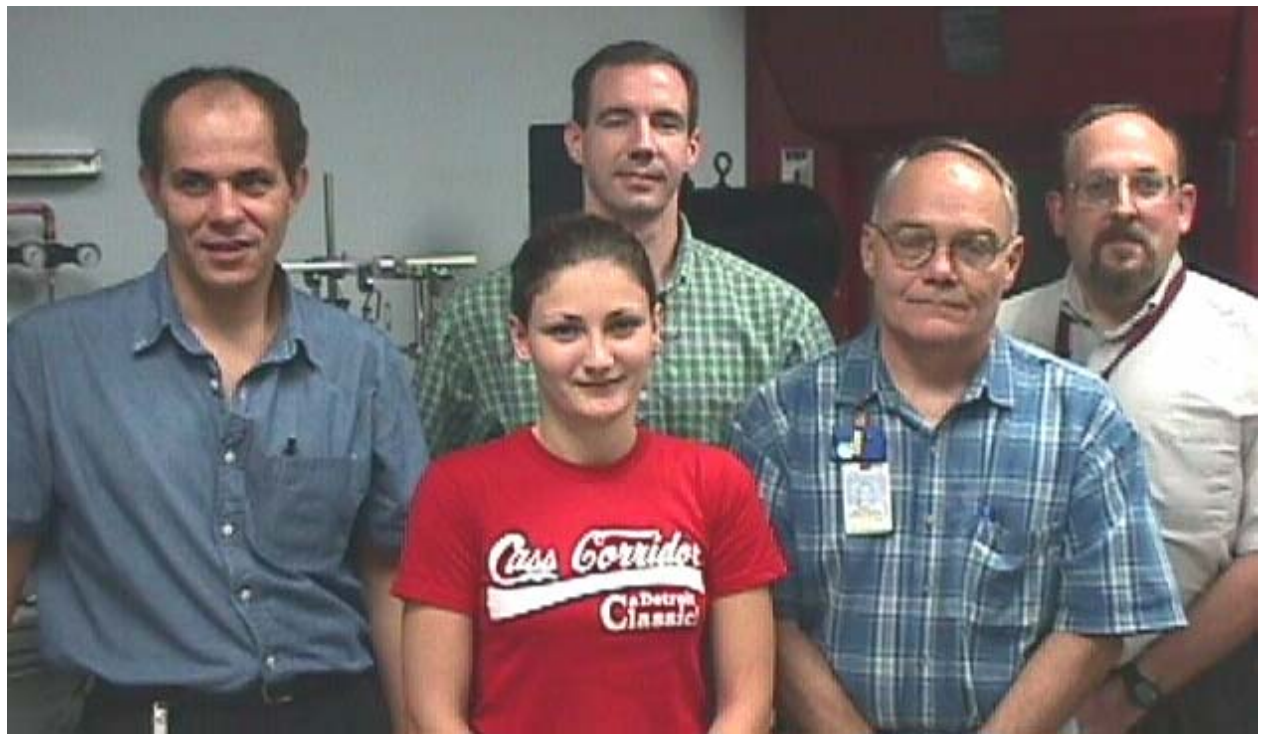

Figure 1. SSBT design team (from left to right: M. Mosleh, D. Dumitrescu (front), R. Ott (rear), J. McLaughlin, P. Blau.

The sub-scale brake material testing system (SSBT) is shown schematically in Figure 2. A 10 h.p., 3-phase, variable-speed motor drives a precision machining spindle upon which was mounted the $127 \mathrm{~mm}$ diameter disc specimen. Spacers were used to reduce heat conduction between the rear of the disc and the face of the drive spindle. The force on the pad specimen was applied using a pneumatic actuator that was damped to avoid impact loading. Tangential force was measured using a load cell attached to a low-friction bearing-mounted, actuator support bracket. The pad specimen, a $12.7 \mathrm{~mm}$ square-faced block was applied to the clockwise-rotating disc at the 9 o'clock position so that the direction of the tangential force was upward.

Test discs were machined from solid test materials and did not contain any ventilation channels or other cooling passages that are used in commercial disc brake rotors. Therefore, they may have run somewhat hotter than actual rotors made from the same materials. The radial distance from the center of the pad specimen contact to the center of the disc was $54.0 \mathrm{~mm}$. Prior to testing, discs were given a circumferential surface lay using 120 grit alumina abrasive paper. The initial centerline average for surface roughness of the discs $\left(\mathrm{R}_{\mathrm{a}}\right)$, measured with a Talysurf $10^{\mathrm{TM}}$ profiling instrument with a $2.5 \mu \mathrm{m}$ tip radius using 7 cut-offs of $0.8 \mathrm{~mm}$, was typically 0.35 to $0.50 \mu \mathrm{m}$. The peak-to-valley roughness was typically $2.0-4.0 \mu \mathrm{m}$. 


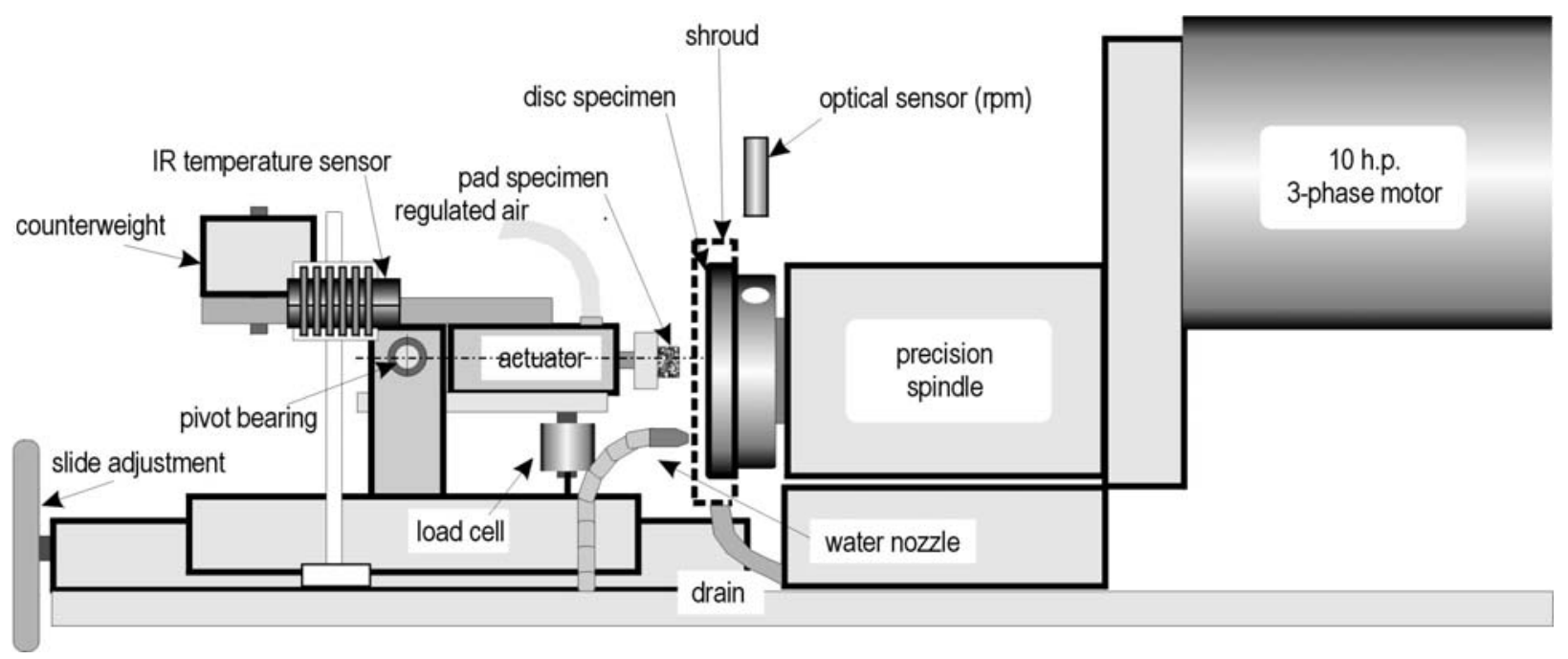

Figure 2. Schematic representation of the sub-scale brake testing system.

An infrared (IR) sensor was used to measure the disc surface temperature at the 1 o'clock position. The emissivity of the transfer film-covered discs was determined with the help of R. Dinwiddie (ORNL) by heating a pre-burnished disc specimen on a hot plate and using a surface thermocouple to calibrate the IR sensor. From time to time, the IR temperature readings were checked using a touch type thermocouple probe on the disc surface immediately after testing. Small adjustments to the emissivity calibration could then be made.

Test data were collected using a customized data acquisition system. Five parameters were recorded for each test: disc rotational speed, pad actuator pressure (normal force), friction force, instantaneous friction coefficient (calculated), and disc surface temperature. Data capture rates of 64 or $128 \mathrm{~s}^{-1}$ were found to be sufficient.

Two normal forces were used: a low value of approximately $161 \mathrm{~N}$, and a higher value or approximately $320 \mathrm{~N}$. Assuming full contact on a pad $12.7 \mathrm{~mm}$ square, these two values produced nominal contact pressures of 1.0 and 2.0 MPa, respectively. Repetitive drags at constant load were applied in each series of runs. The sliding velocities were typically 2, 6, 9.6, or $15 \mathrm{~m} / \mathrm{s}$. Commercial truck disc brakes are available in several diameters; however, for the purposes of estimating equivalent highway speeds, one can assume an outer rotor diameter of $445 \mathrm{~mm}$ and a brake pad width of $90 \mathrm{~mm}$ (in the radial direction) with the center of the swept contact about $200 \mathrm{~mm}$ from the center of wheel rotation.

Assuming that a typical static loaded radius for a commercial truck tire is $0.528 \mathrm{~m}$ and that no slip occurs between the tire and the road surface, the current range of sliding speeds (2, 6, 9.6 and $15 \mathrm{~m} / \mathrm{s})$ correspond respectively, to vehicle speeds of about 19, 57, 91.3, and $142.6 \mathrm{~km} / \mathrm{hr}(11.9,35.7,57.1$, and $89.2 \mathrm{mi} / \mathrm{h}$ ). The Appendix in Ref. [11] shows that there was an excellent correlation between SSBT friction data under certain test conditions and those from full-scale dynamometer tests of the same materials.

\subsection{MATERIALS FOR SUB-SCALE FRICTION AND WEAR TESTS}

Ti-based disc materials and selected properties are listed in Table 1. The materials that were used as sliders are listed in Table 2. Since no friction materials have been developed to serve as brake pads for Ti, and the sliders were chosen from among commercial linings. The semi-metallic JURID 539 ${ }^{\mathrm{TM}}$ is used for truck disc brakes in Europe. The Performance Friction material is a high-performance metallic/ceramic composite. Red Devil Brakes provided linings for their thermally-sprayed Ti rotors. 
Table 1. Titianium-Based Materials Used in SSBT Tests

\begin{tabular}{|c|c|c|c|}
\hline Material (Code) & $\begin{array}{l}\text { Composition (wt\%) or } \\
\text { Method of Preparation }\end{array}$ & $\begin{array}{l}\text { Mechanical and } \\
\text { Thermal } \\
\text { Properties }\end{array}$ & Comments \\
\hline "Ti-6Al-4V (Ti64) & $\begin{array}{l}6.53 \mathrm{Al}, 3.89 \mathrm{~V}, 0.035 \mathrm{Mo}, \\
0.128 \mathrm{Fe}, 0.02 \mathrm{Zr}, 0.024 \mathrm{Si}, \\
0.05 \mathrm{C}, 0.181 \mathrm{O} \text { (Note 1) }\end{array}$ & $\begin{array}{l}\text { UTS }=953 \mathrm{MPa} \\
\text { YS }=878 \mathrm{MPa} \\
\text { Elongation }=12 \% \\
\mathrm{HV}_{2 \mathrm{~N}}=3.36 \mathrm{GPa} \\
k_{t h}=6.83 \mathrm{~W} / \mathrm{m}-\mathrm{K} \\
\rho=4.42 \mathrm{~g} / \mathrm{cc}\end{array}$ & $\begin{array}{l}\text { primary aerospace } \\
\text { alloy from TIMET } \\
\text { Corporation, } \\
\text { Nevada USA; (see } \\
\text { Notes } 2,3 \text { ) }\end{array}$ \\
\hline $\begin{array}{l}\text { Ti-6Al-2Sn-4Zr-2Mo } \\
\text { (Ti6242) }\end{array}$ & $\begin{array}{l}\text { 5.85 Al, 1.95 Mo, 0.06 Fe, } \\
1.98 \mathrm{Sn}, 4.22 \mathrm{Zr}, 0.075 \mathrm{Si}, \\
0.01 \mathrm{C}, 0.09 \mathrm{O} \text { (Note 1) }\end{array}$ & $\begin{array}{l}\text { UTS }=956 \mathrm{MPa} \\
\text { YS = 886 MPa } \\
\text { Elongation }= \\
12.5 \% \\
\mathrm{HV}_{2 \mathrm{~N}}=3.31 \mathrm{GPa} \\
\rho=4.54 \mathrm{~g} / \mathrm{cc}\end{array}$ & $\begin{array}{l}\text { heat-resistant Ti } \\
\text { alloy from TIMET } \\
\text { Corporation, } \\
\text { Nevada USA; (see } \\
\text { Notes } 2,3 \text { for } \\
\text { sources of property } \\
\text { data }\end{array}$ \\
\hline $\begin{array}{l}\text { Thermal spray } \\
\text { coated Ti-6Al-4V } \\
\text { (ThSp) (Note 4) }\end{array}$ & $\begin{array}{l}\text { Ti alloy thermally-sprayed } \\
\text { with a proprietary, two-layer } \\
\text { metal-ceramic coating } \\
\text { approximately } 0.6 \mathrm{~mm} \text { thick }\end{array}$ & $\begin{array}{l}k_{t h}=6.30 \mathrm{~W} / \mathrm{m}-\mathrm{K} \\
\rho=4.42 \mathrm{~g} / \mathrm{cc}(\mathrm{Ti}- \\
6 \mathrm{Al}-4 \mathrm{~V} \text { disk below } \\
\text { the coating })\end{array}$ & $\begin{array}{l}\text { Ti64 disk coated by } \\
\text { Red Devil Brakes, } \\
\text { Mt. Pleasant, PA }\end{array}$ \\
\hline $\begin{array}{l}\text { CermeTi composite } \\
(5 \mathrm{TiB})\end{array}$ & $\begin{array}{l}\text { Particle reinforced } \\
\text { composite produced by cold } \\
\text { plus hot isostatic pressing } \\
(\mathrm{CHIP}) ; 5 \mathrm{wt} \% \mathrm{TiB}_{2}\end{array}$ & $\begin{array}{l}\text { UTS }=1118 \mathrm{MPa} \\
\text { YS }=1008 \mathrm{MPa} \\
\text { Elongation }=3 \% \\
k_{\text {th }}=7.99 \mathrm{~W} / \mathrm{m}-\mathrm{K} \\
\rho=4.34 \mathrm{~g} / \mathrm{cc}\end{array}$ & $\begin{array}{l}\text { Prepared for this } \\
\text { project by Dynamet } \\
\text { Corp., Burlington, } \\
\text { MA (see Note } 2,3 \text { ) }\end{array}$ \\
\hline $\begin{array}{l}\text { CermeTi composite } \\
\text { (10TiB) }\end{array}$ & $\begin{array}{l}\text { Particle reinforced } \\
\text { composite produced by cold } \\
\text { plus hot isostatic pressing } \\
(\mathrm{CHIP}) ; 10 \text { wt\% TiC }\end{array}$ & $\begin{array}{l}\text { UTS }=987 \mathrm{MPa} \\
\text { YS }=953 \mathrm{MPa} \\
\text { El. }=1.5 \% \\
k_{t h}=8.21 \mathrm{~W} / \mathrm{m}-\mathrm{K} \\
\rho=4.44 \mathrm{~g} / \mathrm{cc}\end{array}$ & $\begin{array}{l}\text { Prepared for this } \\
\text { project by Dynamet } \\
\text { Corp., Burlington, } \\
\text { MA (see Notes 2,3) }\end{array}$ \\
\hline $\begin{array}{l}\text { CermeTi composite } \\
\text { (WTiC) }\end{array}$ & $\begin{array}{l}\text { particle reinforced } \\
\text { composite produced by cold } \\
\text { plus hot isostatic pressing } \\
\text { (CHIP); } 7.5 \text { wt } \% \text { W mixed } \\
\text { with an composite of Ti-6Al- } \\
4 \mathrm{~V} \text { containing } 7.5 \text { wt } \% \text { TiC }\end{array}$ & $\begin{array}{l}\text { UTS }=1022 \mathrm{MPa} \\
\text { YS }=1015 \mathrm{MPa} \\
\text { El. }=1 \% \\
k_{\text {th }}=6.57 \mathrm{~W} / \mathrm{m}-\mathrm{K} \\
\rho=4.68 \mathrm{~g} / \mathrm{cc}\end{array}$ & $\begin{array}{l}\text { Prepared for this } \\
\text { project by Dynamet } \\
\text { Corp., Burlington, } \\
\text { MA (see Notes } 2,3 \text { ) }\end{array}$ \\
\hline $\begin{array}{l}\text { ORNL TiB }_{2} \\
\text { Composite (30TiB) }\end{array}$ & $\begin{array}{l}30 \text { weight } \% \mathrm{TiB}_{2} \text {, mixed } \\
\text { into Ti powder layer, then } \\
\text { pressed and sintered onto a } \\
\text { Ti powder substrate }\end{array}$ & $\rho=4.46 \mathrm{~g} / \mathrm{cc}$ & $\begin{array}{l}\text { Prepared at Oak } \\
\text { Ridge National } \\
\text { Laboratory }\end{array}$ \\
\hline
\end{tabular}

Note 1) Analysis of the heat of material used in these tests was provided by TIMET Corp., Nevada USA

Note 2) Tensile properties from the supplier of the material, Vickers hardness tests done at ORNL.

Note 3) Thermal conductivities of the test materials were measured by $\mathrm{H}$. Wang, ORNL Note 4) G. Martino, "Brake Rotors with Heat-Resistant Ceramic Coatings," U.S. Patent, $5,901,818$ (May 11, 1999). 
Table 2. Friction Materials Used in SSBT Tests

\begin{tabular}{|l|l|l|}
\hline \hline SLIDER MATERIALS & \multicolumn{2}{c|}{ Description } \\
\hline $\begin{array}{l}\text { Brake lining, JURID 539 } \\
\text { (JURID) }\end{array}$ & $\begin{array}{l}\text { proprietary semi-metallic } \\
\text { composition used in truck air disk } \\
\text { brakes }\end{array}$ & $\begin{array}{l}\text { Product of Knorr- } \\
\text { Bremse, Germany }\end{array}$ \\
\hline $\begin{array}{l}\text { Commercial lining, } \\
\text { Performance Friction Carbon } \\
\text { Metallic type 10 (PF CM10) }\end{array}$ & $\begin{array}{l}\text { proprietary, brake lining } \\
\text { formulation for high-performance, } \\
\text { high-heat applications }\end{array}$ & $\begin{array}{l}\text { Performance Friction, } \\
\text { Clover, SC USA. }\end{array}$ \\
\hline Commercial lining RD 8 (A) & $\begin{array}{l}\text { proprietary, medium to high-torque } \\
\text { formulation designed for sports } \\
\text { cars; brake temperatures 120-540 } \\
\text { C. }\end{array}$ & $\begin{array}{l}\text { Red Devil Brakes, Mt. } \\
\text { Pleasant, PA USA }\end{array}$ \\
\hline Commercial lining RD 4 (B) & $\begin{array}{l}\text { high torque pad designed for circle } \\
\text { track cars under 1270 kg weight; } \\
\text { brake temperatures 200 - 650 C. }\end{array}$ & $\begin{array}{l}\text { Red Devil Brakes, Mt. } \\
\text { Pleasant, PA USA }\end{array}$ \\
\hline Commercial lining RD 14 (C) & $\begin{array}{l}\text { very high torque formulation with } \\
\text { aggressive initial bite, designed for } \\
\text { cars with high deceleration rates } \\
\text { and down forces; brake } \\
\text { temperatures 150 to 870 C. }\end{array}$ & $\begin{array}{l}\text { Red Devil Brakes, Mt. } \\
\text { Pleasant, PA USA }\end{array}$ \\
\hline Commercial lining RD 15 (D) & $\begin{array}{l}\text { similar characteristics to RD 14 } \\
\text { but for vehicles with lower down } \\
\text { forces. }\end{array}$ & $\begin{array}{l}\text { Red Devil Brakes, Mt. } \\
\text { Pleasant, PA USA }\end{array}$ \\
\hline $\begin{array}{l}\text { Commercial lining RD 589A } \\
\text { (E) }\end{array}$ & $\begin{array}{l}\text { highly-metallic formulation } \\
\text { recommended for Ti-based rotors }\end{array}$ & $\begin{array}{l}\text { Red Devil Brakes, Mt. } \\
\text { Pleasant, PA USA }\end{array}$ \\
\hline
\end{tabular}

A summary of the results can be found in an ORNL Technical Report [6]; however, selected data will be reproduced here for convenience. Baseline SSBT friction data for cast iron sliding against several commercial lining materials, including two from Table 2, are given in Figure 3. 


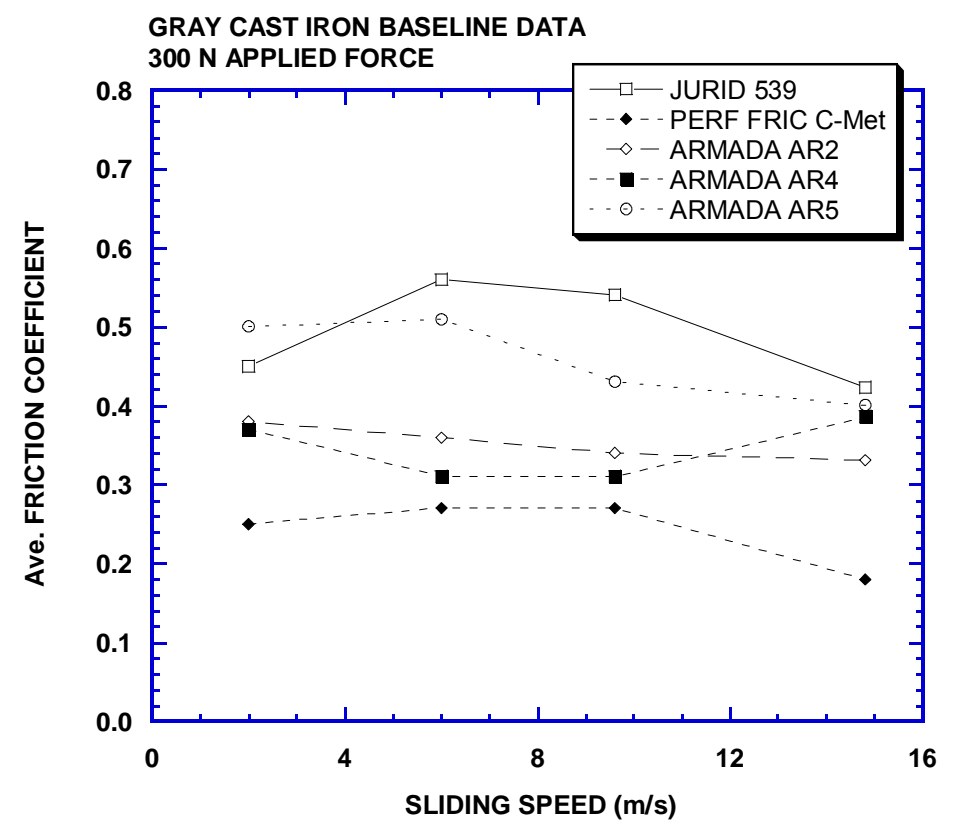

Figure 3. Average friction coefficient per drag for cast iron discs at higher normal force $(300 \mathrm{~N})$. Each datum is the average of five drags.

The JURID material tended to produce higher values over the range of drag speeds and the Performance Friction material produced the lowest values. The Armada materials also shown in Figure 3 are used for drum-type brakes in heavy trucks. Typical brakes range in friction coefficient from about 0.30 to 0.55 . In contrast to the data in Fig. 3, typical results for bare Ti alloy discs show a declining friction coefficient as speed increases (Fig 4.) At $9.6 \mathrm{~m} / \mathrm{s}$, the friction has reached marginally satisfactory levels.

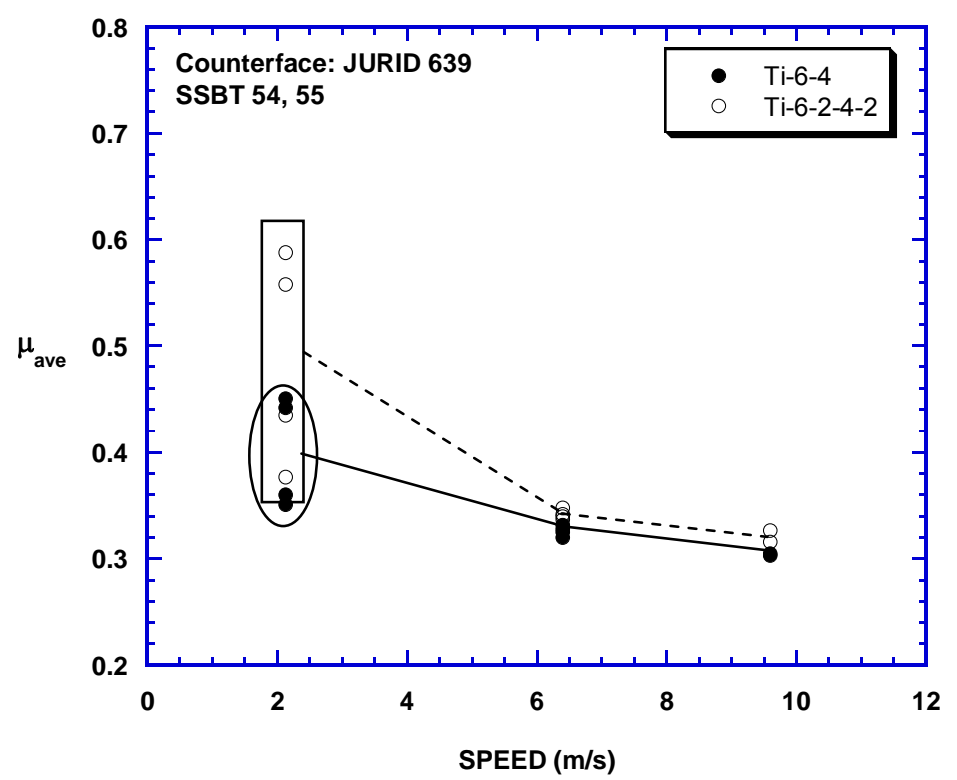

Figure 4. Average friction coefficient versus sliding speed for two titanium alloys sliding against a JURID pad. Differences were greatest at low speed. 
In comparison to the Ti-6Al-4V and Ti-6Al-2Sn-4Zr-2Mo titanium alloys, the friction coefficient of Ti-based composites (with the possible exception of 10\% TiC) also decreased with speed (see Fig. 5, plotted from a data table in Ref. [11]). Values for the composites were also on the low side of those typical for automotive and truck brakes.

In contrast to tests on $\mathrm{Ti}$ alloys and composites, results for the thermally-spray coated Ti-6Al-4V (TSTi) indicated that friction coefficient rose as the sliding speed (and temperature) increased (Fig. 6). While the tests using TSTi material ran hotter than those using cast iron, they did not exhibit the potentially dangerous decrease in friction with temperature that is called "fade." Consequently, the ability of the TSTi to provide braking power when hot is an attractive feature and may be suitable for applications, like delivery trucks, trash haulers, and buses in which there are frequent stops with little convective cooling.

Since the friction coefficients were somewhat lower than might be desired for normal braking, it was decided to investigate the effects of surface roughness on friction. Roughness increases the grip of a surface and can accelerate the production of a beneficial transfer film from material on the lining side of the couple. The effects of as-ground versus as-thermally-sprayed surfaces on the friction-induced temperature rise are shown in Figure 7. Grinding the deposit reduced friction and hence sliding temperature rise.

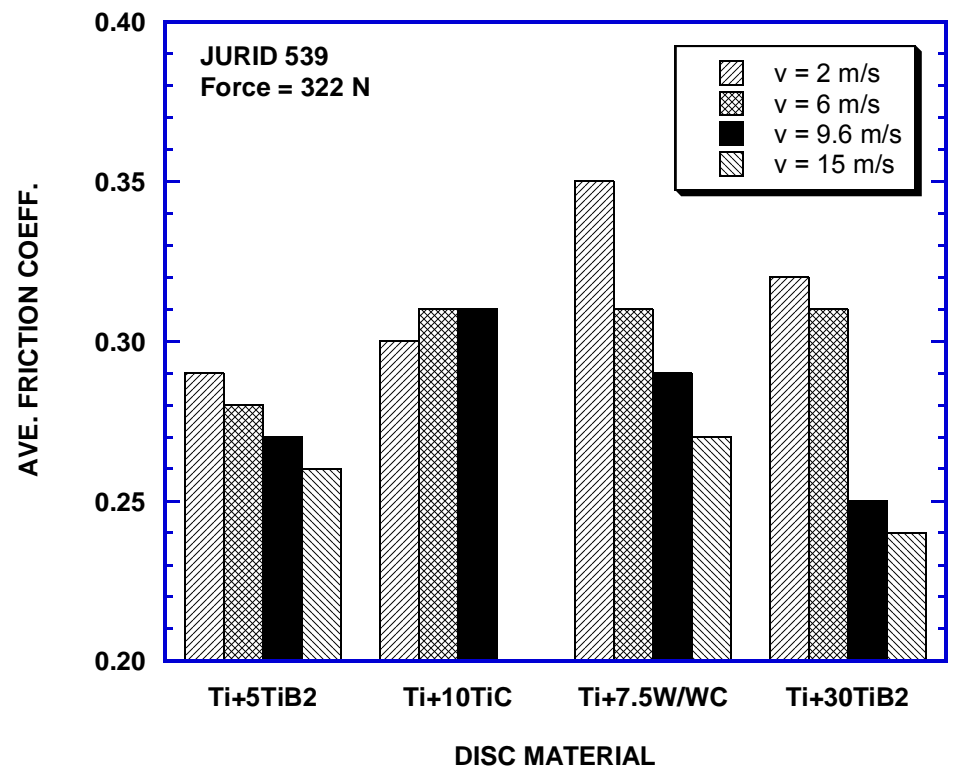

Figure 5. Average sliding friction coefficients for titanium composites against JURID pad material at different sliding speeds (data from Ref. [11]). 


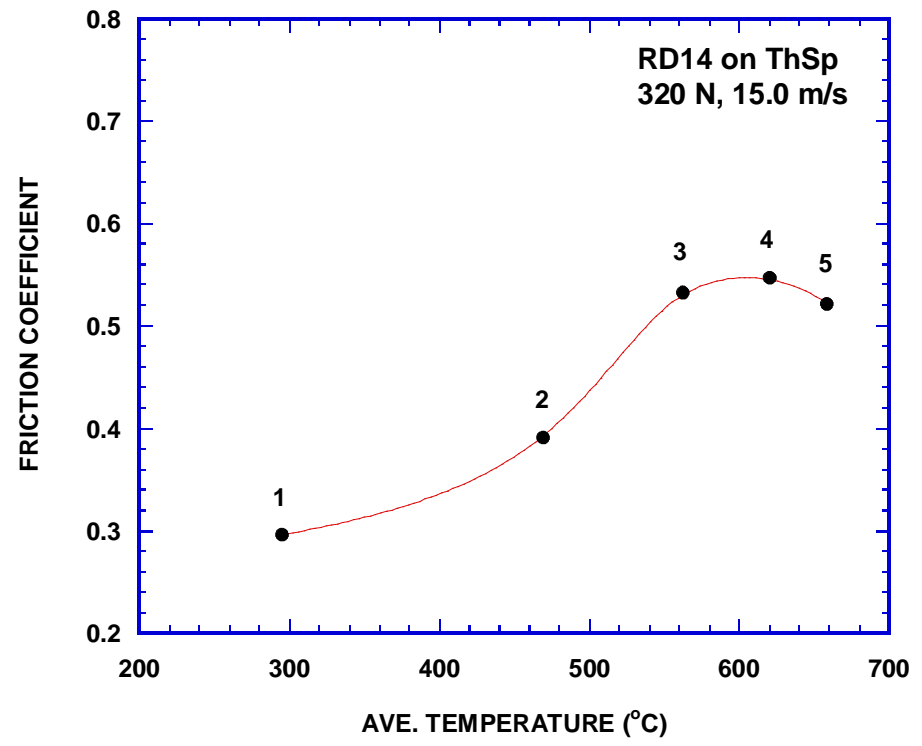

Figure 6. Effect of disc surface temperature on the friction coefficient the TSTi against Red Devil pad RD14.

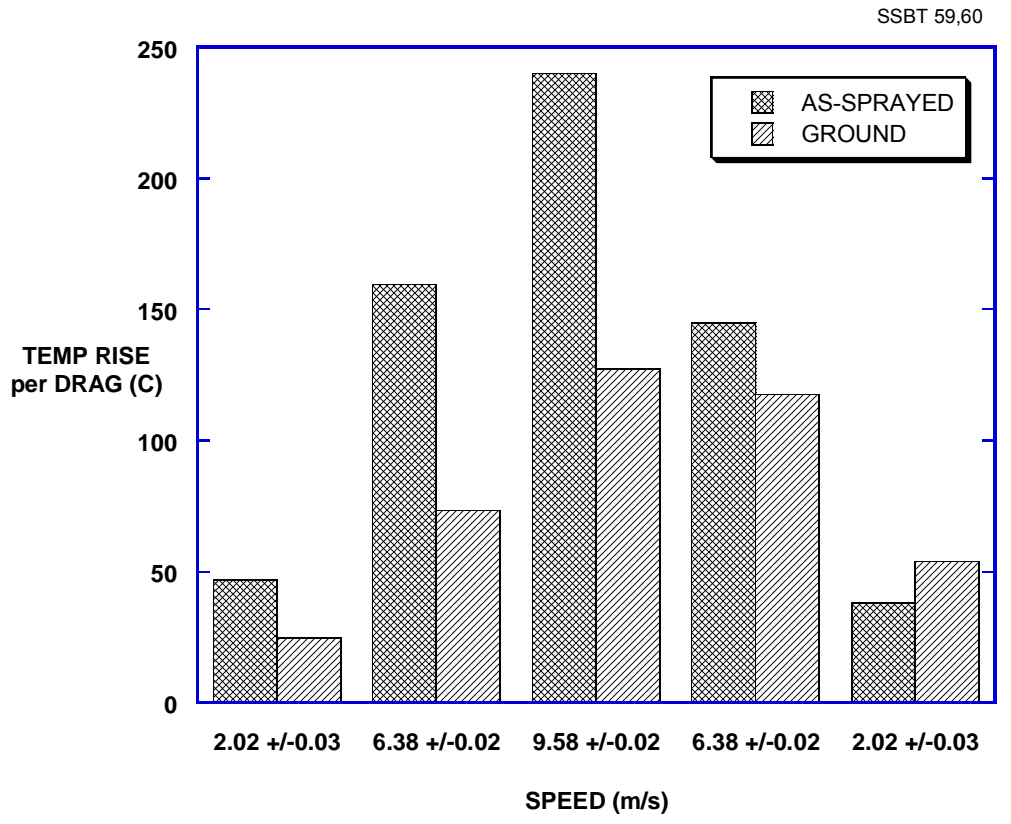

Figure 7. The as-sprayed TSTi showed higher friction and frictional heating than a similar deposit that was sprayed and then ground smooth.

At sliding speeds up to about $10 \mathrm{~m} / \mathrm{s}$, friction of the $30 \%$ TiB2 composite produced by W. Peter (ORNL) using low cost Ti powders tended to decrease with subsequent drags, but at the highest sliding speed of $15 \mathrm{~m} / \mathrm{s}$, the friction increased (Fig. 8). This increase was similar to that for the TSTi at high speed, suggesting that Ti brakes may perform better when hot. 


\subsection{SURFACE OXIDATION TREATMENTS}

Recent studies by Jun Qu (ORNL) indicate that surface oxidation treatments can be beneficial to the friction and wear of Ti alloys This was demonstrated by conducting a series of tests of oxidized Ti under conditions similar to those used for the other Ti-based materials. As shown in Figure 9, the surface treated materials produced higher friction coefficients that varied little with the sliding speed. This material offers significant promise for further development.

\subsection{WEAR}

Wear data for the base alloys and the various Ti-based composites (other than the TSTi materials) has been presented elsewhere [11]. It was found that adding hard particles to a Ti alloy matrix can substantially improve its wear resistance, but gray cast iron had slightly better wear resistance when tested under the conditions of this study. More research is needed on the wear of the TSTi composites, particularly with pad materials that might produce more favorable results.

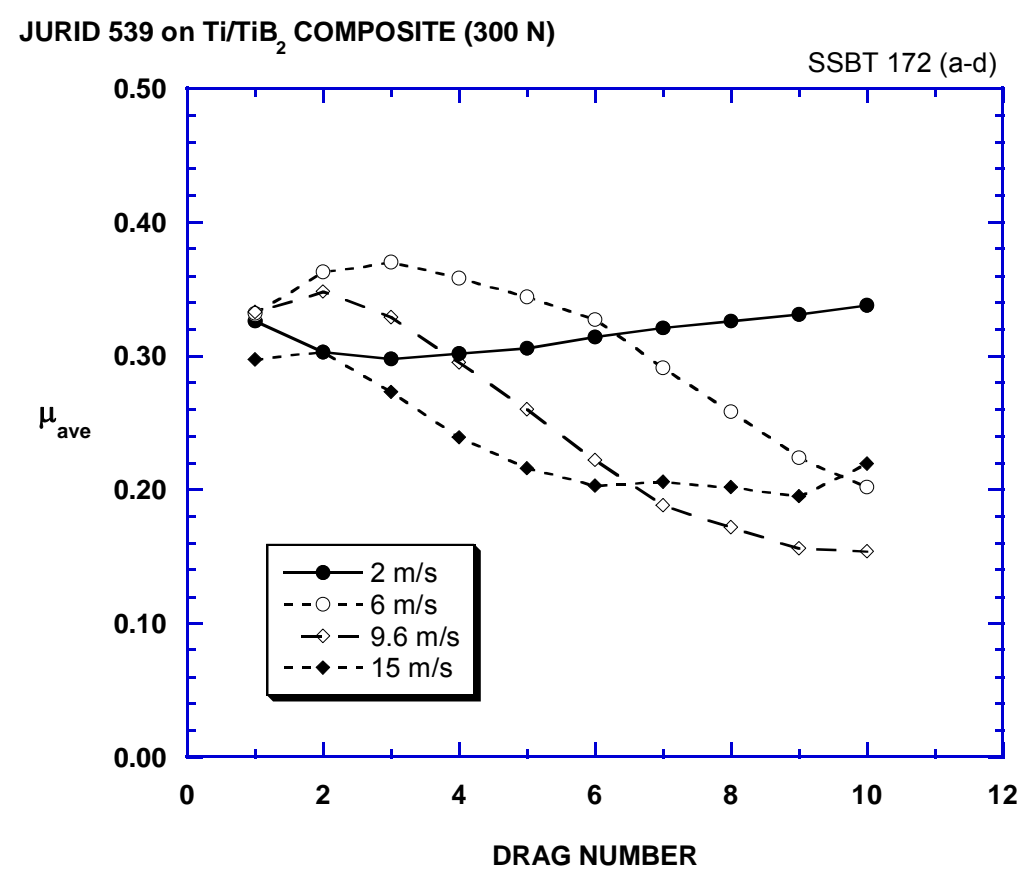

Figure 8. Friction coefficient changes with repeated drags at various speeds for $\mathrm{Ti}+30 \% \mathrm{TiB} 2$ against JURID pad material. 


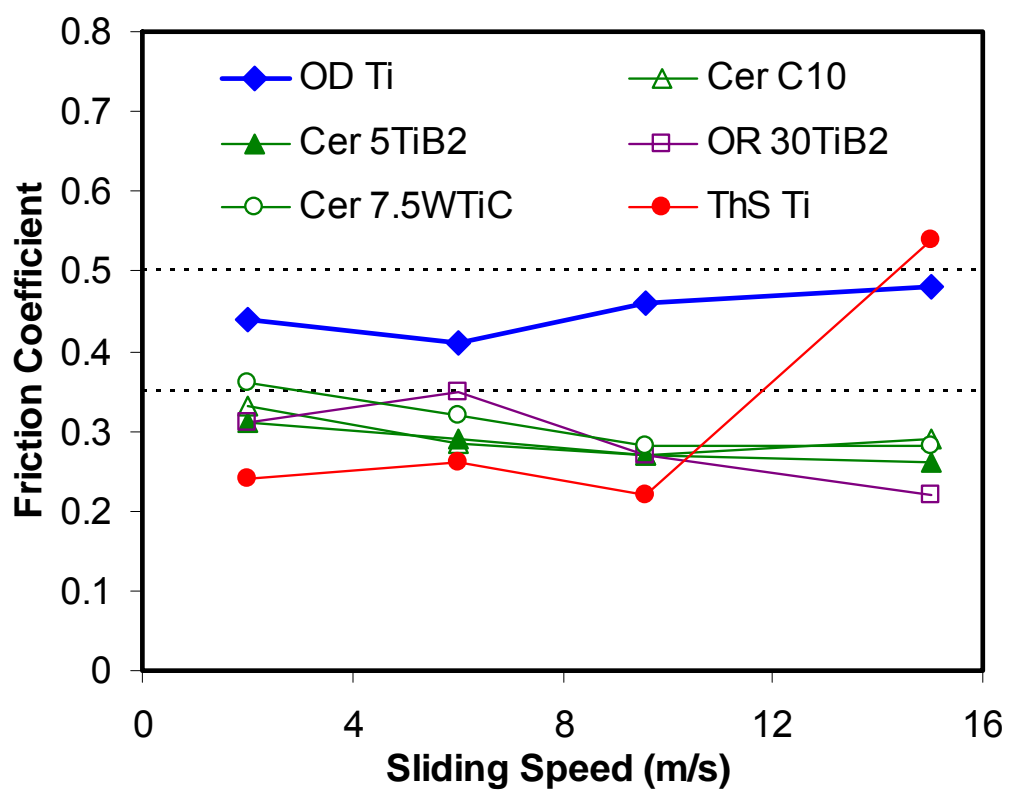

Figure 9. OD (oxidation treated) Ti-6Al-4V alloy discs had the highest stable friction coefficient against the JURID 539 material under most test conditions.

\section{SUMMARY OF DYNAMOMETER TESTS ON A FULL-SCALE TITANIUM ROTOR}

Full-scale, truck-sized titanium brake rotors were prepared by Red Devil Brakes, Inc., based on a commercial design. These were used to conduct standard industry tests of Ti brake rotor performance. Results of these tests, conducted at a commercial dynamometer testing facility in the Detroit area, are provided here.

\subsection{MATERIALS}

Four full-sized, investment-cast titanium alloy rotors were prepared by Red Devil Brakes, Inc., Mt. Pleasant, Pennsylvania, using designs for a commercial hydraulic truck rotor. Rotors were subsequently thermally-sprayed with a proprietary, ceramic-containing coating that was approximately 1$2 \mathrm{~mm}$ thick [21]. One of the four test rotors is shown in Figure 10. A polished cross-section of the coating was prepared and it shows a metallic bonding layer next to the titanium substrate and an upper friction surface layer (Figure 11). 


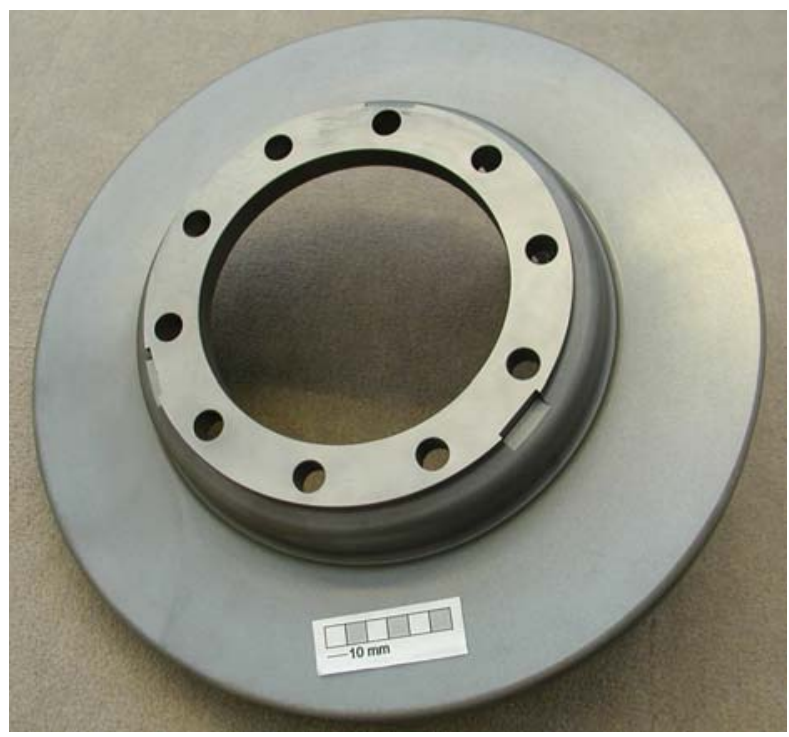

Figure 10. Titanium alloy truck brake rotor with a protective thermally-sprayed coating applied to the friction surfaces.

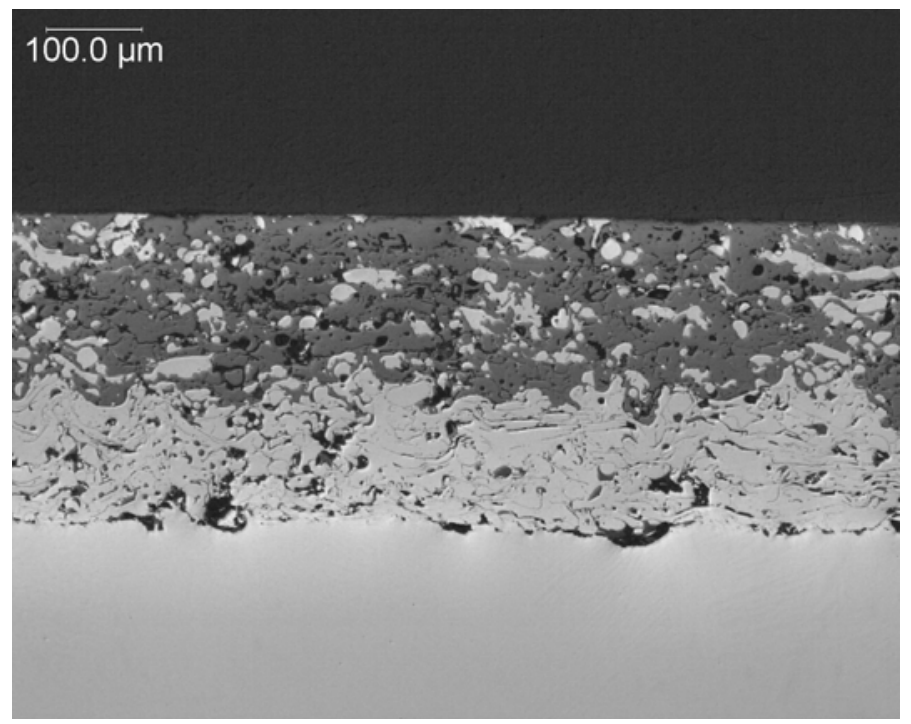

Figure 11. Cross-section of the thermally-sprayed coating similar to those used in this work.

\subsection{THERMAL IMAGING}

In a series of initial tests conducted at a commercial brake supplier's laboratory, a TSTi rotor was compared to the performance of gray cast iron. This pad was an experimental Ferodo composition. R. Dinwiddie recorded several of those tests with an infrared (IR) camera and measured the temperature rise as a function of sliding conditions. In general, the Ti rotor ran several hundreds of degrees $\mathrm{C}$ hotter than the cast iron under similar conditions. A thermal image of the rotor is shown in Figure 12. Part of the circular rotor is covered by the test fixture and calipers, but the trailing edge of the caliper contact is at the bottom, where the color is most intense. 


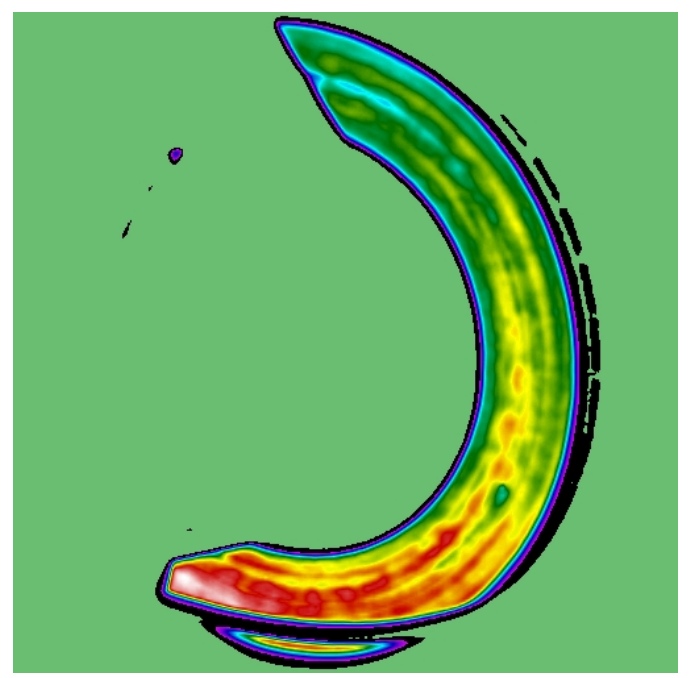

Figure 12. Infrared image of a Ti-based brake rotor (similar to that in Fig. 10) undergoing repeated stops from 50 to $15 \mathrm{mph}$.

\subsection{DESCRIPTION OF THE MATERIALS AND DYNAMOMETER TEST}

Table 3 lists the material pairings that were used in the subsequent investigation at Link Testing Laboratories, Detroit, Michigan. A total of six tests were conducted. The rationale for the tests was as follows:

- The cast iron original equipment rotor and pads were used as a baseline for comparison

- The grooved rotor was tested using a fully-metallic pad formulation recommended by Red Devil Brakes for its thermally-sprayed surfaces.

- The tests using other commercial pad materials were used to determine the performance of alternative pad materials for this kind of rotor.

It should be stressed that only the Red Devil Type 589 pad materials were designed for use with the rotor coating being tested, but that the optimization of the pad composition has yet to be completely achieved. 
Table 3. Combinations of Materials Subjected to Dynamometer Testing

\begin{tabular}{|l|l|c|}
\hline \multicolumn{1}{|c|}{ Rotor } & \multicolumn{1}{|c|}{ Pad Designation } & $\begin{array}{c}\text { Test ID } \\
\text { Code }\end{array}$ \\
\hline $\begin{array}{l}\text { Cast iron (Quadraulic }{ }^{\text {TM }} \text { front disc) } \\
\text { Dayton part number 23123557 }\end{array}$ & $\begin{array}{l}\text { Delphi product DAD769GM brake } \\
\text { pads for 4 x 70 mm calipers }\end{array}$ & REF \\
\hline Thermally-sprayed Titanium (grooved) & $\begin{array}{l}\text { Red Devil Type 589A fully-metallic } \\
\text { pad }\end{array}$ & RD1 \\
\hline Thermally-sprayed Titanium (grooved) & $\begin{array}{l}\text { Red Devil Type 589A fully-metallic } \\
\text { pad }\end{array}$ & RD2 \\
\hline Thermally-sprayed Titanium & GEMPCO G-1 lining product & GEM \\
\hline Thermally-sprayed Titanium & Ferodo H lining product & FER \\
\hline Thermally-sprayed Titanium & HAWK H-T-15 lining product & HWK \\
\hline
\end{tabular}

The test used in this investigation was recommended by Tim Duncan of Link Testing Laboratories. It is the provisional test ISO 26867 and titled: "Road Vehicles - Brake Linings - Friction Materials: Inertia Dynamometer Friction Behavior Assessment for Automotive Brake Systems.” It was modified to include a 90 miles per hour maximum speed to fully test the titanium under high-energy braking. It is a procedure with growing popularity for hydraulic disc brakes of the type tested here. A summary of the 20-section, 175 brake applications procedure is presented in Table 4 . Each section of the procedure tests a different characteristic of brake performance. In addition, wear data for the rotor and the pad materials are also obtained.

\subsection{TEST RESULTS}

Each seven-page test report for ISO 26867 contains thousands of data readings from the computercontrolled dynamometer procedure in addition to a number of time axis plots of pressure, friction, and rotor temperature in addition to friction data histograms. For the purposes of this report, the data have been distilled and summarized in Table 5. The numbered notes below the table refer to the sections of the test that resulted in those data. 
Table 4. Summary of ISO 26867 Dynamometer Test Procedure for Disc Brakes

\begin{tabular}{|c|c|c|c|}
\hline Name of Section & Description & $\begin{array}{l}\text { Number of } \\
\text { Stops or } \\
\text { Snubs* }\end{array}$ & $\begin{array}{c}\text { Initial Rotor } \\
\text { Temperature } \\
\left({ }^{\circ} \mathrm{C}\right)\end{array}$ \\
\hline $\begin{array}{l}\text { Green } \mu \\
\text { characteristic }\end{array}$ & $\begin{array}{l}\text { Prior to burnishing the friction } \\
\text { material or the rotor surface }\end{array}$ & 10 & 150 \\
\hline Burnish & $\begin{array}{l}\text { Stops at different deceleration rates } \\
\text { to condition the friction surfaces }\end{array}$ & 32 & 200 \\
\hline $\begin{array}{l}\text { Characteristic value } \\
\text { (stability check) }\end{array}$ & $\begin{array}{l}\text { Determine the reference value for } \\
\text { friction to compare to later }\end{array}$ & 5 & 150 \\
\hline Ramp applications & Snubs under increasing pressure & 2 & 100 \\
\hline $\begin{array}{l}\text { (Cold) Characteristic } \\
\text { section }\end{array}$ & Low rotor temperature snubs & 6 & $\begin{array}{l}1 \text { stops at } 40 \\
5 \text { stops at } 150\end{array}$ \\
\hline $\begin{array}{l}\text { Low speed / low } \\
\text { pressure (1) }\end{array}$ & Three snubs each at 20 and $30 \mathrm{kph}$ & 6 & 150 \\
\hline Pressure line (1) & $\begin{array}{l}\text { Snubs at pressures from 1-12 MPa } \\
\text { in } 1 \mathrm{MPa} \text { increments }\end{array}$ & 9 & 150 \\
\hline Speed line & Snubs at various speeds & 6 & 150 \\
\hline Failed booster & $\begin{array}{l}\text { Stops at the same speed but } \\
\text { different temperatures }\end{array}$ & 6 & $\begin{array}{l}1 \text { at } 65 \\
5 \text { at } 150\end{array}$ \\
\hline $\begin{array}{l}\text { Motorway } \\
\text { applications }\end{array}$ & $\begin{array}{l}\text { Snubs under two different } \\
\text { decelerations }\end{array}$ & 2 & 150 \\
\hline $\begin{array}{l}\text { Low speed / low } \\
\text { pressure (2) }\end{array}$ & Three snubs each at 20 and $30 \mathrm{kph}$ & 6 & 150 \\
\hline $\begin{array}{l}\text { Characteristic } \\
\text { recovery (1) }\end{array}$ & Snubs from $80-30 \mathrm{kph}$ & 10 & 150 \\
\hline Fade (1) & Snubs from 100-20 kph & 15 & $150-550$ \\
\hline Hot performance & $\begin{array}{l}\text { Ramping up temperature by } \\
\text { applying repeated snubs from } 80 \text { to } \\
40 \mathrm{kph}\end{array}$ & 9 & $\begin{array}{c}\geq 500 \text { for disc } \\
\text { brakes }\end{array}$ \\
\hline $\begin{array}{l}\text { Low speed / low } \\
\text { pressure ( } 3 \text { ) }\end{array}$ & Three snubs each at 20 and $30 \mathrm{kph}$ & 6 & 150 \\
\hline $\begin{array}{l}\text { Characteristic } \\
\text { recovery }(2)\end{array}$ & Snubs from $80-30 \mathrm{kph}$ & 10 & 150 \\
\hline Pressure line (2) & $\begin{array}{l}\text { Snubs at pressures from 1-12 MPa } \\
\text { in } 1 \mathrm{MPa} \text { increments }\end{array}$ & 9 & 150 \\
\hline Fade (2) & Snubs from 100-20 kph & 15 & $150-550$ \\
\hline $\begin{array}{l}\text { Low speed / low } \\
\text { pressure (4) }\end{array}$ & Three snubs each at 20 and $30 \mathrm{kph}$ & 6 & 150 \\
\hline Final characteristic & Snubs from $80-20 \mathrm{kph}$ & 5 & 150 \\
\hline Lining wear & $\begin{array}{l}\text { (measurements of mass and } \\
\text { thickness) }\end{array}$ & & \\
\hline
\end{tabular}

${ }^{*}$ A snub is a deceleration between two speeds. A stop refers to full deceleration to zero speed.

Note that there were several anomalous occurrences in the course of testing. Testing of the 589A pad material had to be stopped at the beginning of the second fade section because a portion of the welded pad broke off after significant vibration and noise. This is probably a consequence of the manner used to prepare the pad specimens by cutting and welding tiles onto a steel backing plate especially for these tests. It may not represent the pad material's performance but rather the method used to prepare test 
coupons of the lining material. There was an incidence in which a section of the thermal sprayed coating appeared to spall off from the rotor surface (test ID: HWK). It should be recalled that the current test method is a particularly severe procedure and was intended to test the materials under rather extreme conditions.

Table 6 includes data on maximum temperatures and temperature rises. These are not included in the data summary for ISO 26867 but are included within the larger body of data. As was observed in laboratory tests and in earlier dynamometer tests run at a major dynamometer facility in Detroit, the titanium rotors ran hotter than the cast iron. The RD 289A lining ran hotter than the others, but the coated rotor run against it was cooler that the other titanium rotors under similar conditions. The ratio of the lining temperature rise to the rotor temperature rise in line 3 of Table 6 is a rough estimate of the partition of frictional heating between the lining and the rotor. The RD lining stands out from the others in terms of lining to rotor temperature ratio because its higher metallic content promoted heat conduction into the lining.

The data in Tables 7 and 8 have been plotted in Figures 13 through 19 to enable easier, visual comparisons of certain data. Figure 13 indicates the maximum temperatures of rotor and pad materials after the final snub in the hot performance section of the procedure. Figure 14 summarizes minimum, average, and maximum friction coefficients for the tests excluding the hot performance and fade sections. Figure 15 shows the friction coefficients for the post-burnish run, and the minima for the hot performance and high-speed segments of the test. Figures 16 and 17 display the pad wear data and Figures 18 and 19 the rotor wear data. In one instance (test ID: HWK), the spall from the rotor prevented obtaining an accurate post-test wear measurement. 
Table 5. ISO 26867 Dynamometer Test Data Summary

\begin{tabular}{|l|c|c|c|c|c|c|}
\hline \multicolumn{1}{|c|}{ Quantity } & Note & REF & RD & GEM & FER & HWK \\
\hline \hline Nominal $\mu$ & 1 & 0.351 & 0.297 & 0.280 & 0.318 & 0.398 \\
\hline Minimum $\mu$ & 2 & 0.182 & 0.167 & 0.095 & 0.104 & 0.115 \\
\hline Maximum $\mu$ & 3 & 0.555 & 0.510 & 0.394 & 0.450 & 0.567 \\
\hline Green effect. min. $\mu$ & 4 & 0.238 & 0.246 & 0.252 & 0.237 & 0.140 \\
\hline Post-burnish average $\mu$ & 5 & 0.416 & 0.281 & 0.298 & 0.344 & 0.469 \\
\hline Low v-p max. $\mu$ & 6 & 0.555 & 0.510 & 0.394 & 0.435 & 0.542 \\
\hline Low v-p min. $\mu$ & 7 & 0.193 & 0.290 & $($ Note 21$)$ & 0.228 & 0.290 \\
\hline Speed sensitivity (\%) & 8 & -18 & 6 & -8 & -7 & -8 \\
\hline High-speed min $\mu$ & 9 & 0.264 & 0.213 & 0.207 & 0.194 & 0.231 \\
\hline $\begin{array}{l}\text { Pre-fade pressure sens. } \\
\text { (\%) }\end{array}$ & 10 & -30 & -7 & -23 & -26 & -29 \\
\hline $\begin{array}{l}\text { Post-fade pressure sens. } \\
\text { (\%) }\end{array}$ & 11 & -6 & 0 & -22 & -28 & -28 \\
\hline Fade 1, min. $\mu$ & 12 & 0.182 & 0.172 & 0.152 & 0.104 & 0.115 \\
\hline Hot perform. min. $\mu$ & 13 & 0.226 & 0.167 & 0.182 & 0.156 & 0.181 \\
\hline Fade 2, min. $\mu$ & 14 & 0.184 & 0.175 & 0.095 & 0.180 & 0.118 \\
\hline Post fade ave. $\mu$ & 15 & 0.209 & $($ note 20$)$ & - & 0.274 & 0.383 \\
\hline Wear, ave pad thick. & 16 & 4.245 & 1.732 & 8.708 & 4.170 & 4.236 \\
\hline Wear, ave. rotor thick. & 17 & -0.0038 & 0.0352 & 0.1391 & 0.019 & 0.168 \\
\hline Wear, ave. pad wt loss. & 18 & 199.1 & 66.3 & 464.5 & 105.0 & 182.0 \\
\hline Wear, ave. rotor wt loss. & 19 & -1.800 & -2.5 & 24.1 & 2.3 & 93. \\
& & & & & & (Note 22) \\
\hline
\end{tabular}

\section{Explanatory notes:}

1) Average $\mu$ for all brake applies, but not counting the fade and hot performance sections.

2) Lowest average minimum $\mu$ for all brake applies, but not counting the fade and hot performance sections.

3) Highest average maximum $\mu$ for all brake applies, but not counting the fade and hot performance sections.

4) Minimum $\mu$ during the green effectiveness section.

5) Average $\mu$ during the characteristic stability check section.

6) Minimum $\mu$ during all four low speed and pressure sections.

7) Maxmum $\mu$ during all four low speed and pressure sections.

8) Percent $\mu$ variation between the results at 160 and $80 \mathrm{kph}$ lines.

9) Minimum $\mu$ from 180 and $200 \mathrm{kph}$ sections.

10) Percent $\mu$ variation between the $6 \mathrm{MPa}$ pressure and the $2 \mathrm{MPa}$ pressure before the first fade section.

11) Percent $\mu$ variation between the $6 \mathrm{MPa}$ pressure and the $2 \mathrm{MPa}$ pressure after the first fade section.

12) Minimum $\mu$ during the first fade section.

13) Minimum $\mu$ at $500^{\circ} \mathrm{C}$.

14) Minimum $\mu$ during the second fade section.

15) Average $\mu$ during the final characteristic check section.

16) Average pad thickness loss for the inner and outer pads in $\mathrm{mm}$ (loss is positive, gain is negative).

17) Average rotor thickness loss in $\mathrm{mm}$ (loss is positive, gain is negative).

18) Average pad weight loss for the inner and outer pads in grams (loss is positive, gain is negative). 
19) Average rotor weight loss in grams (loss is positive, gain is negative).

20) Operator had to stop the test at the beginning of the second fade due to excessive oscillation. Part of the welded brake pad broke off and led to large torque variations. This was a noisy test as well.

21) The first reading in the third low pressure/low speed section registered a zero. This may be an anomalous reading.

22) A portion of the coating on the rotor spalled off and was documented photographically. This led to the excessive weight loss.

Table 6. Summary of Temperature Data from ISO 26867 Dynamometer Tests

\begin{tabular}{|l|c|c|c|c|c|}
\hline \multicolumn{1}{|c|}{ Lining Material Test Codes } & REF & RD & GEM & FER & HWK \\
\hline $\begin{array}{l}\text { 1) Max rotor temp. at the end of the } \\
\left.\text { last hot performance stop ( }{ }^{\circ} \mathrm{C}\right)\end{array}$ & 578 & 601 & 681 & 641 & 691 \\
\hline $\begin{array}{l}\text { 2) Max lining temp. at the end of the } \\
\left.\text { last hot performance stop ( }{ }^{\circ} \mathrm{C}\right)\end{array}$ & 594 & 822 & 709 & 778 & 757 \\
\hline $\begin{array}{l}\text { 3) Ratio of lining temp. to rotor } \\
\text { temp. (from lines 1,2 above) - heat } \\
\text { partition }\end{array}$ & $\mathbf{1 . 0 3}$ & $\mathbf{1 . 3 7}$ & $\mathbf{1 . 0 4}$ & $\mathbf{1 . 2 1}$ & $\mathbf{1 . 0 9}$ \\
\hline $\begin{array}{l}\text { 4) Rotor temp. rise for first apply in } \\
\left.\text { the hot performance section ( }{ }^{\circ} \mathrm{C}\right)\end{array}$ & 17 & 39 & 70 & 110 & 151 \\
\hline $\begin{array}{l}\text { 5) Rotor temp. rise for last apply in } \\
\text { the hot performance section }\left({ }^{\circ} \mathrm{C}\right)\end{array}$ & 78 & 101 & 82 & 141 & 191 \\
\hline
\end{tabular}




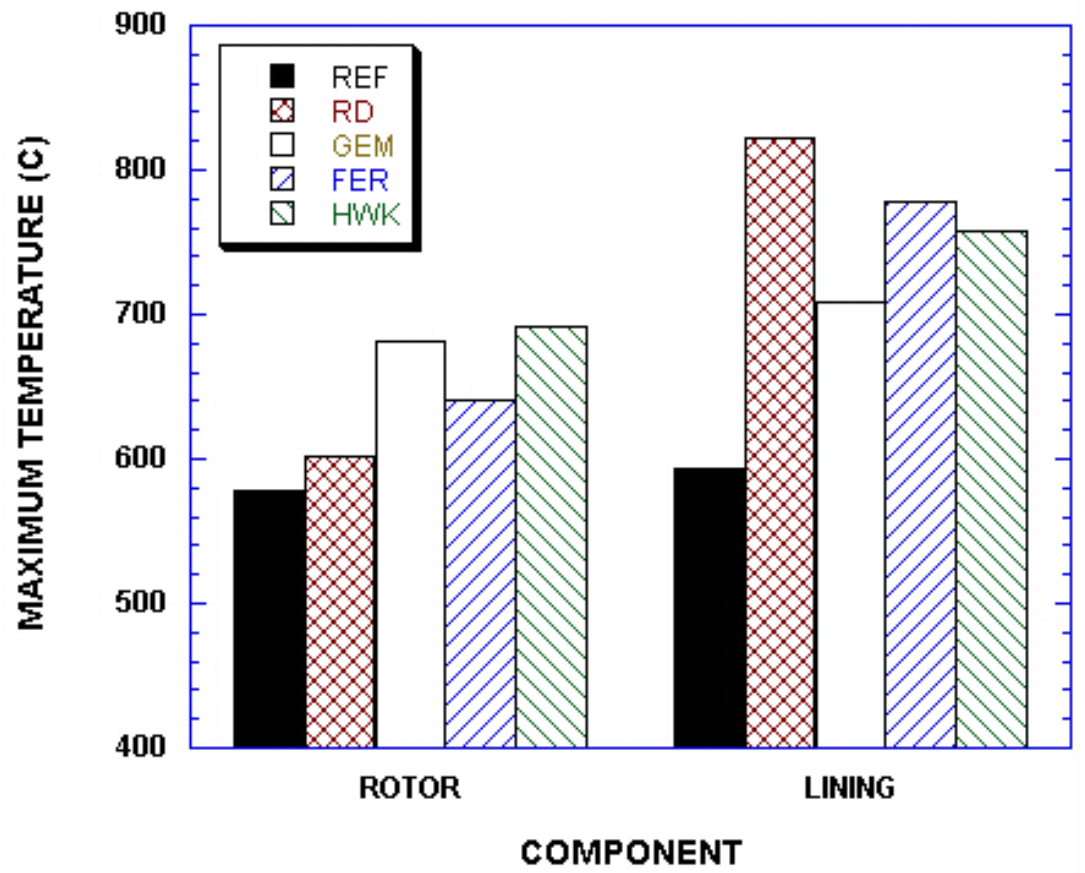

Figure 13. Maximum temperatures of the rotor and pad after the last stop in the hot performance series of applies

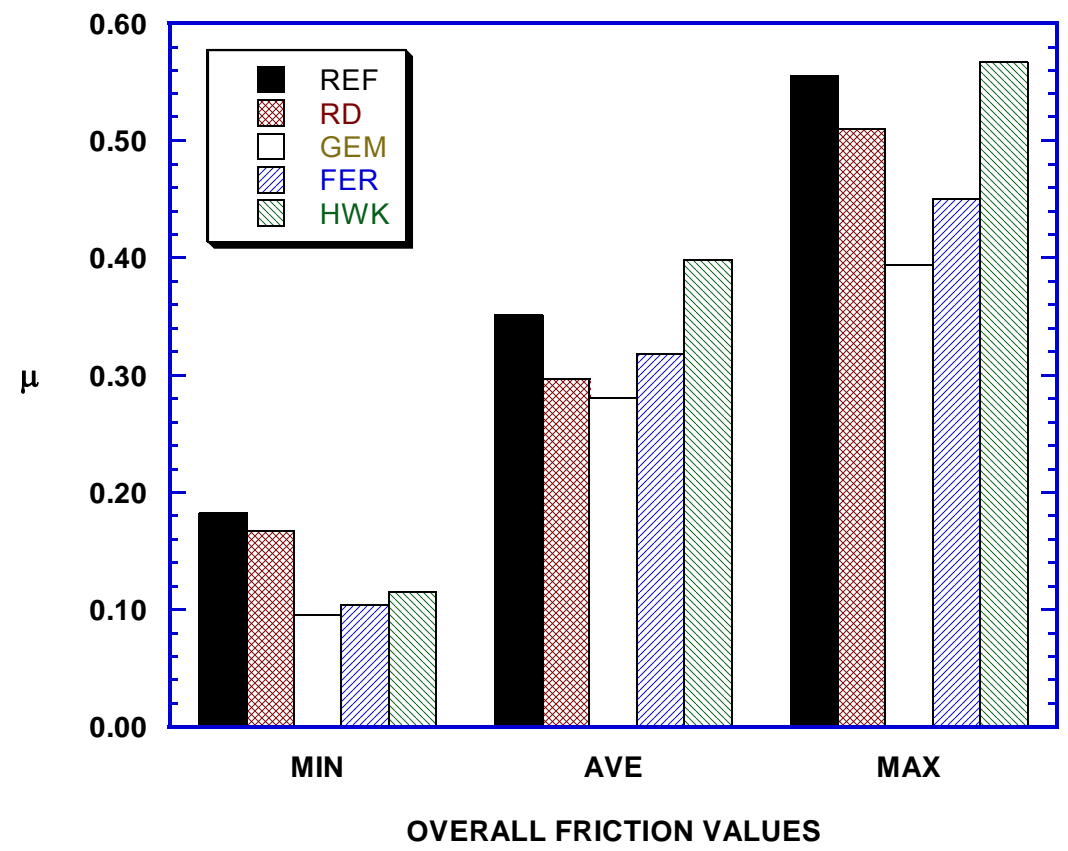

Figure 14. Minimum, maximum and average friction coefficients for all tests except the fade and hot sections of the procedure 


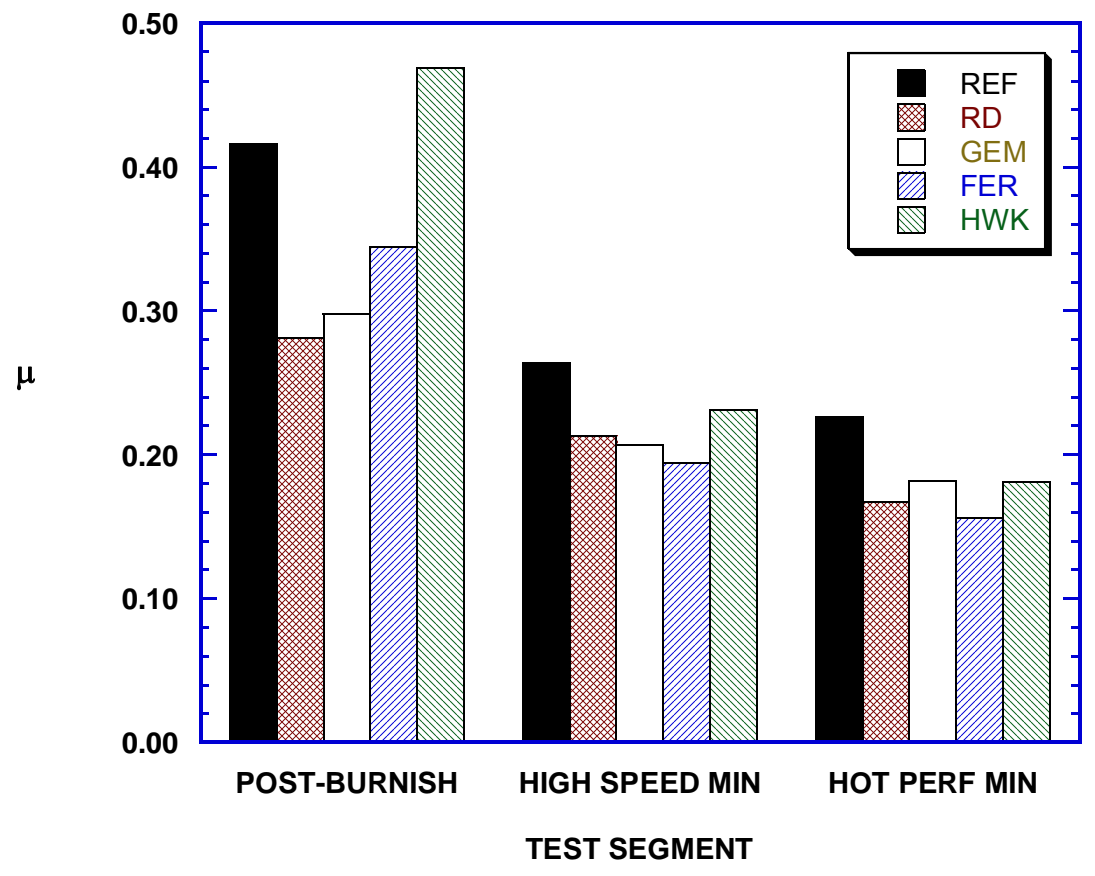

Figure 15. Friction values for post-burnish, high-speed, and hot performance tests.

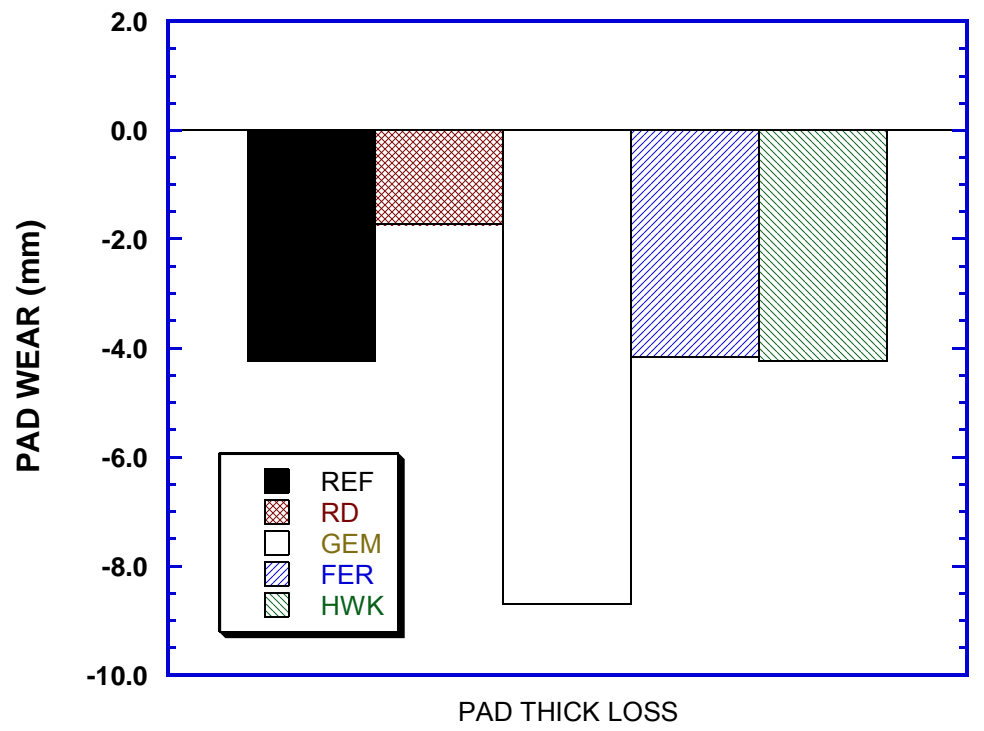

Figure 16. Final pad wear loss as measured by thickness change. 


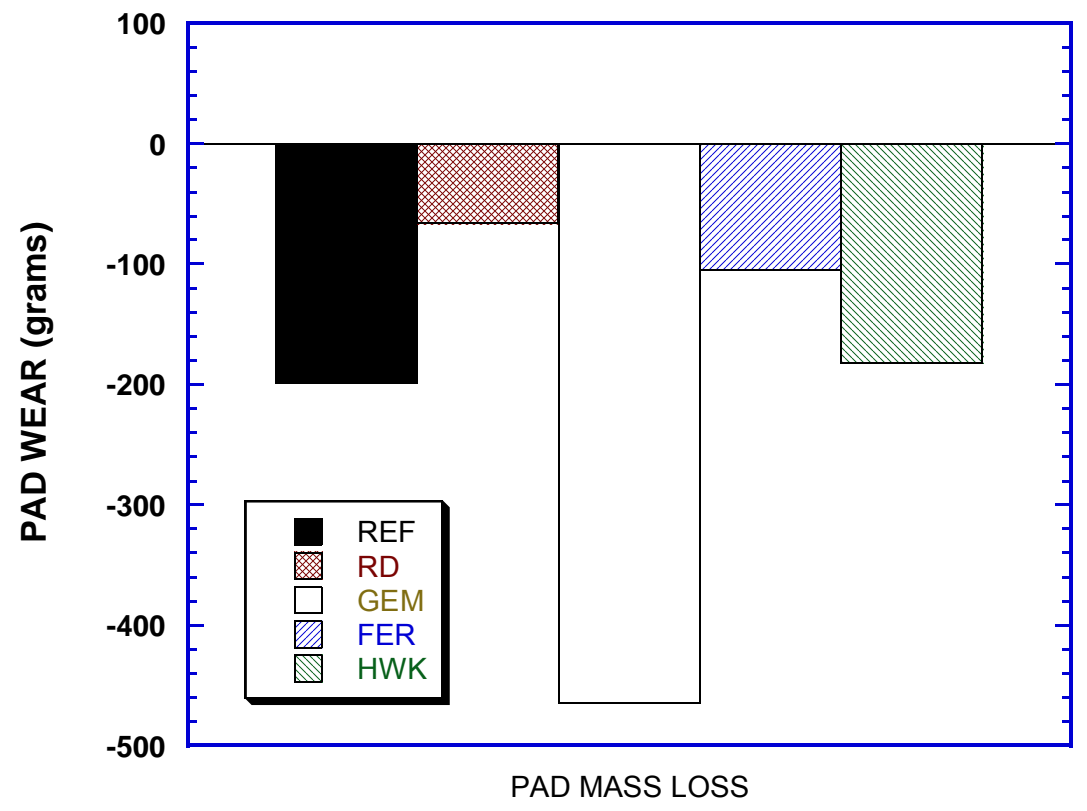

Figure 17. Final pad wear loss by mass change.

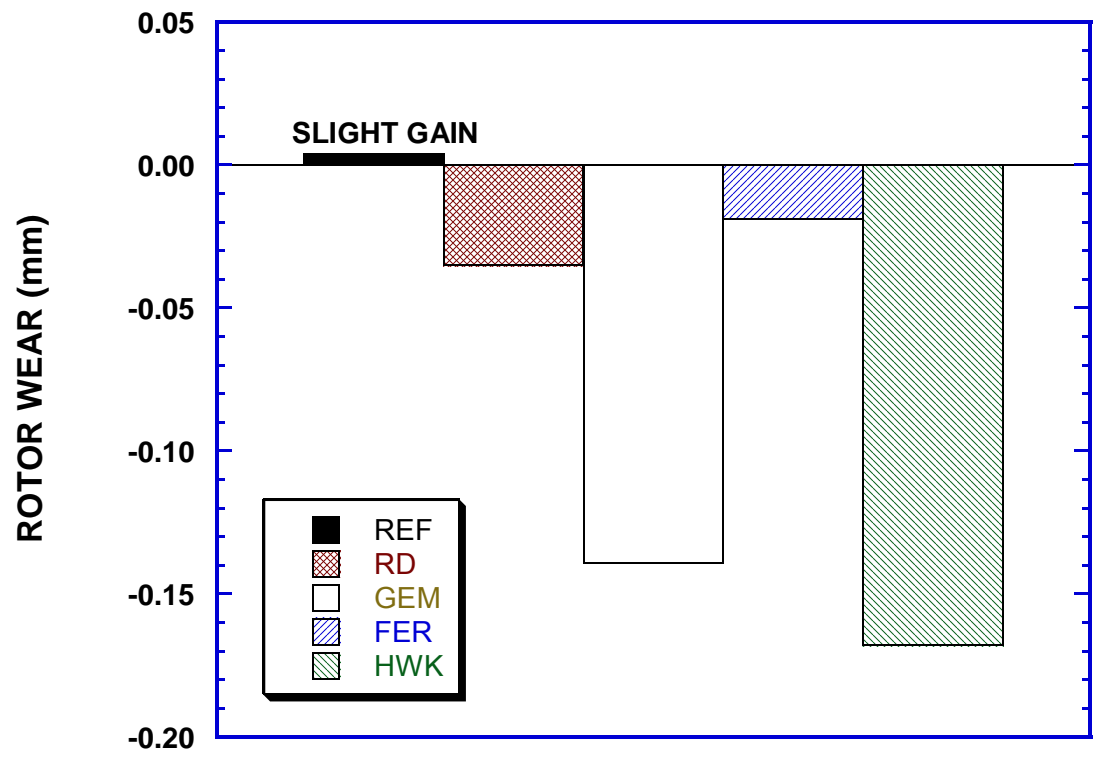

Figure 18. Final rotor wear by thickness change. 


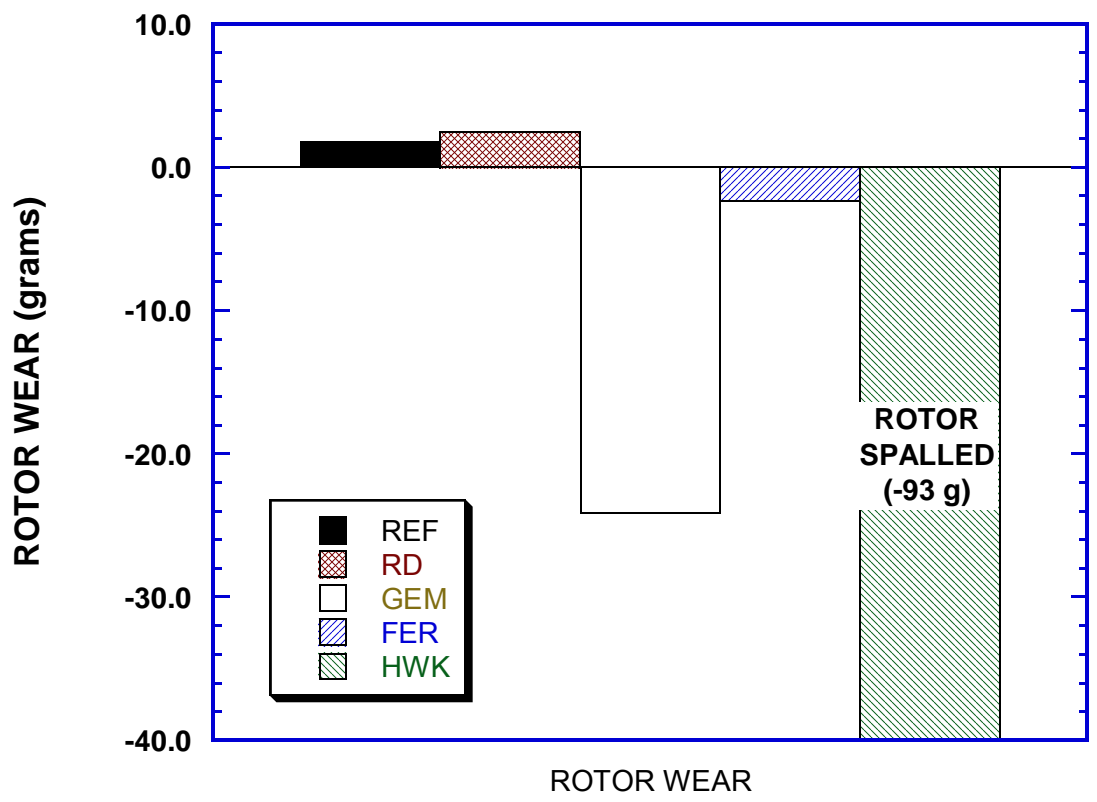

Figure 19. Final rotor wear by mass change.

\subsection{DISCUSSION AND CONCLUSIONS (DYNAMOMETER TESTS)}

These dynamometer tests were conducted in part with experimental materials and with lining samples that were assembled to fit the available calipers. Only one test was performed for each material combination within the available time and resources; therefore, the statistical variability for these results could not be established and all results should be considered preliminary.

- Except for the Hawk lining against thermally-sprayed titanium, minimum, average, and maximum friction coefficients for the titanium rotors were lower that those for the cast iron rotor and lining combination.

- Relative to cast iron, maximum temperatures were higher for thermally-sprayed titanium rotor surfaces and pads, as might be expected from prior laboratory tests and the low thermal conductivity of Ti relative to Fe.

- Of the titanium rotors, the rotor for the RD 589A couple ran coolest and the pad hottest during the hot performance test section. This is reflected in the ratio of maximum lining temperature to maximum rotor temperature for the series of sliding pairs.

- The RD 589A pad material had the least wear of all other pad materials, including the OE material run against cast iron.

- After testing, the cast iron rotor seemed to gain both thickness and weight, presumably due to the presence of transfer films from the linings. All of the thermally-sprayed titanium rotors except one lost thickness and mass. 


\subsection{SUMMARY AND CONCLUSIONS}

Based on laboratory-scale and dynamometer tests of candidate Ti-based brake rotor materials, the following general conclusions can be drawn:

1) Titanium alloys can be used for ground vehicle friction brakes, but surface treatments for improved friction and wear control, and a design that accommodates higher frictional temperatures must be employed for successful implementation.

2) Adding hard particles to the Ti alloys improves their wear resistance over non-reinforced alloys, but not to the current level of cast iron rotors.

3) A proprietary thermally-sprayed coating produced encouraging results in laboratory and dynamometer tests, but seemed to perform better when hot than at lower braking energy conditions when the rotors were only warm.

4) Titanium brake rotors ran several hundred degrees $C$ hotter than a cast iron rotor tested under similar dynamometer conditions. Brake hardware made from Ti will need to be designed to account for these characteristics and should not simply be substituted for cast iron using the same designs.

5) Better brake lining materials, optimized for the Ti-based rotors, need to be developed and tested. Probably they will require a higher metallic content to help conduct heat away and also will need to provide acceptable wear lives for both pads and rotors.

6) Particulate composites prepared from low cost $\mathrm{Ti}$ powders (with $30 \% \mathrm{TiB}_{2}$ ) and test discs made from Ti-6Al-4V alloys that were oxygen diffusion-treated seemed to perform better frictionally than bare Ti alloys and other Ti-based composites in laboratory tests. These observations suggest the need for further research on both low-cost composites and surface treatments for Ti. 


\section{REFERENCES}

1. L. C. Buckman (1998) "Commercial Vehicle Braking Systems: Air Brakes, ABS and Beyond,” Soc. Auto. Engr., SP-1405, Warrendale, PA, 172 pp.

2. P. J. Blau (2001) "Compositions, Functions, and Testing of Friction Brake Materials and Their Additives,” Oak Ridge National Laboratory Tech. Report, ORNL/TM 2001/64, Oak Ridge, Tennessee, 24 pp.

3. G. Nicholson (1995) Facts About Friction, Gedoran Publishing, Winchester, VA, 260 pp.

4. S. Ozcan and P. Filip (2005) “Microstructure and wear mechanisms in C/C composites,” Wear 259, pp. 642-650.

5 V. Kervorkjian (2002) “Ceramic Brake Rotor for Passenger Cars,” Bull. Amer. Cer. Soc., 82/4, pp. 27-29.

6. E. H. Kraft (2002) "Opportunities for Low Cost Titanium in Reduced Fuel Consumption, Improved Emissions, and Enhanced Durability Heavy-Duty Vehicles,” Oak Ridge National Laboratory Tech. Report ORNL/Sub/4000013062/1, Oak Ridge, Tennessee, 59 pp.

7. J. Sweet (2004) “STOP! Improve your Corvette’s braking performance almost 36 percent with Red Devil pads and rotors," Corvette Fever, May (2004).

8. K. G. Budinski (1991) “Tribological properties of titanium alloys,” Wear 151, 203-217.

9. A. Molinari, T. B. Straffelini, and T. Bacci (1997) "Dry sliding wear mechanisms of the Ti6Al4V alloy,” Wear 208, pp. 105-112.

10. J. Qu, P. J. Blau, and N. S. Kulkarni (2005) "Unusual Sliding Friction and Wear Behavior of Titanium Alloys against Metal, Polymer, and Ceramic Counterfaces,” Wear 258, pp. 1348-1356.

11. P. J. Blau (2004) "Research on Non-Traditional Materials for Friction Surfaces in Heavy Vehicle Disk Brakes,” Oak Ridge National Laboratory Technical Report, ORNL/TM-2004/265, 32 pp.

12. P. J. Blau, R. L. Martin, M. H. Weintraub, H. Jang, and W. Donlon (1996) "Frictional Behavior of Automotive Brake Materials Under Wet and Dry Conditions," Oak Ridge National Laboratory Technical Report, ORNL/M-5824, 41 pp.

13. P. J. Blau (2000) "Energy Efficiency in Heavy Vehicle Tires, Drivetrains, and Braking Systems - A Multi-Year Program Plan,” Oak Ridge National Laboratory Tech. Report, ORNL/TM-2000/177, 10 pp.

14. P. J. Blau (2001) "A Review of Sub-Scale Test methods to Evaluate the Friction and Wear of Ring and Liner Materials for Spark- and Compression-Ignition Engines,” Oak Ridge National Laboratory Tech. Report, ORNL/TM-2001/184, 19 pp. 
15. D. F. Wilson, E. A. Kenik, and P. J. Blau (2002) "Evaluation of Corrosion Failure in TractorTrailer Brake System,” Oak Ridge National Laboratory Tech. Report, ORNL/TM-2002/161, 21 pp.

16. P. J. Blau (2004) "Research on Non-Traditional Materials for Friction Surfaces in Heavy Vehicle Disc Brakes,” Oak Ridge National Laboratory Tech. Report, ORNL/TM-2004/265, 31 pp.

17. P. J. Blau and J. C. McLaughlin (2003) "Effects of Water Films and Sliding Speed on the Frictional Behavior of Truck Disc Brake Materials,” Tribology International, 36 (10), pp. 709-715.

18. P. J. Blau and H. M. Meyer III (2003) “Characteristics of Wear Particles Produced during Friction Tests of Conventional and Non-Conventional Disc Brake Materials,” Wear 255, 1261-1269.

19. M. Mosleh, P. J. Blau, and D. Dumitrescu (2004) "Characteristics and morphology of wear particles from laboratory testing of disk brake materials,” Wear 256, pp. 1128-34.

20. P. J. Blau and B. C. Jolly (2005) "Wear of truck brake lining materials using three different test methods,” Wear 259 (Part 1), pp. 1022-1030

21. P. J. Blau, B. C. Jolly, W. H. Peter, and C. A. Blue (2007) “Tribological Investigation of TitaniumBased Materials for Brakes,” Wear (in press).

22. G. Martino (1999) "Brake rotors with heat-resistant ceramic coatings, U. S. Patent 5,901,818. 


\section{INTERNAL DISTRIBUTION}

1. D. R. Johnson, 4515, MS-6066

2-6. $\quad$ P. S. Sklad, 4515, MS-6065 (5 copies)

$7 . \quad$ J. Qu, 4515, MS-6063

8-12. P. J. Blau, 4515, MS-6063 (5 copies)

13. R. B. Dinwiddie, 4515, MS-6065

14. W. Peter, 4508, MS-6083

15. C. A. Blue, 4508, MS-6083

16. Lab Records, 4500N, MS-625

17. ORNL Central Research Library, 4500N, MS-6191

\section{EXTERNAL DISTRIBUTION}

18. Rogelio A. Sullivan, U.S. Department of Energy,EE-2G, Rm 5G-046,1000 Independence Avenue SW, Washington, DC 20585

19. Jerry Gibbs, Office of FreedomCAR and Vehicle Technology, Dept. of Energy - EE-2G, 1000 Independence Avenue SW., Washington, DC 20585

20. Joseph Carpenter, Office of FreedomCAR and Vehicle Technologies U.S. Dept. of Energy Suite 5G-046, Org Code EE-2G 1000 Independence Avenue, SW, Washington, D.C. 20585

21. Brent Armentrout, Haldex Brake Systems Division, Friction Product Center, 629 Copperfield Lane, Tipp City, OH 45371

22. James Clark, Dana Corporation, Spicer Heavy Axle \& Brake Division, PO Box 4097, Kalamazoo, MI 49003-4097

23. Chris Demas, Kenworth Truck Company, PO Box 1000 (98083-1000), Kirkland, WA 98033

24. Richard Diemer, Brakepro, LTD., 1612 Callie Way Drive, Franklin, TN 37064

25. Tim Duncan, Link Testing Laboratories, Inc., 13840 Elmira Avenue, Detroit, MI 48227-3017

26. Charles Greening, Jr, Greening Test Labs, 19465 Mt. Elliot Ave., Detroit, MI 48234-2786

27. Roy Link, President, Link Engineering Company, 43855 Plymouth Oaks Blvd., Plymouth, MI 48170-2585

28. Gerald Martino, President, Red Devil Brakes, Inc., Rd 6, Box 2391, Mt. Pleasant, Pa. 15666

29. Rodger Seeley, Hendrickson International, 532 Romero St., Stratford ONT, N5A 7X1 CANADA

30. Skip Yaekel, Volvo Trucks North America, Inc.,7900 National Service Road, Greensboro, NC 27402-6115

31. Randy Petresh, Haldex Brake Systems,10707 N.W. Airworld Drive, Kansas City, MO 641531215

32. James P. Theuerkauf, CVS Advanced Engineering, Meritor Heavy Vehicle Systems LLC, 2135 West Maple Rd, Troy, MI 48084

33. Edwin H. Kraft, 10917 SE Burlington Dr., Vancouver, WA 98664-5383 